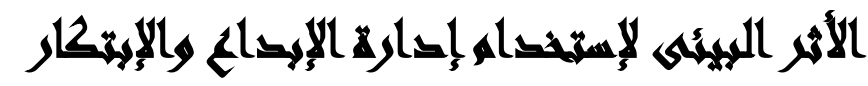

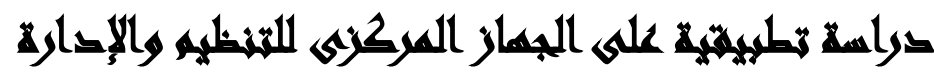

[iv]

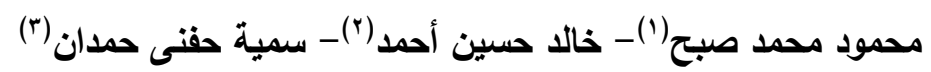

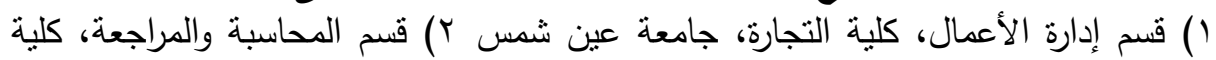

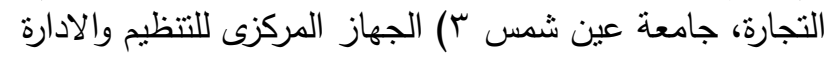

\section{المستخلئ}

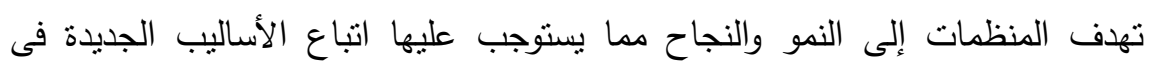

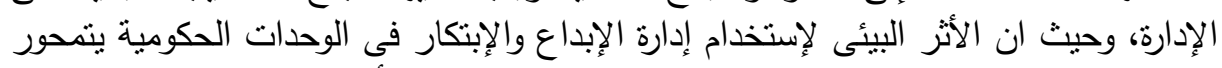

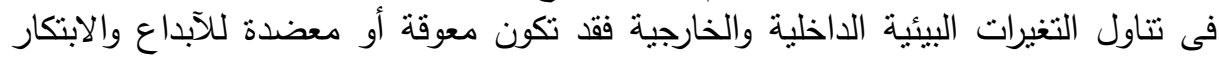

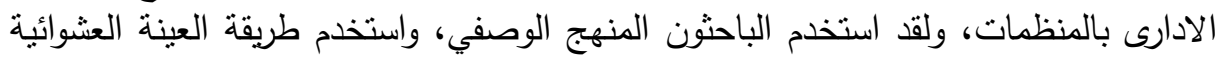

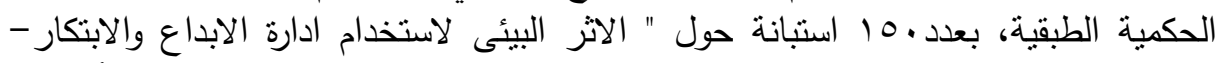

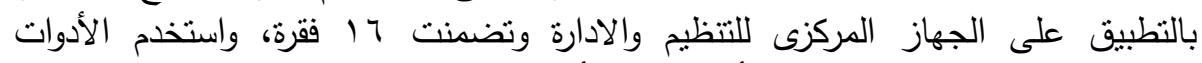

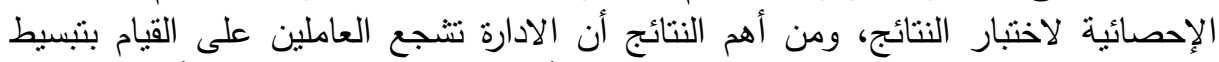

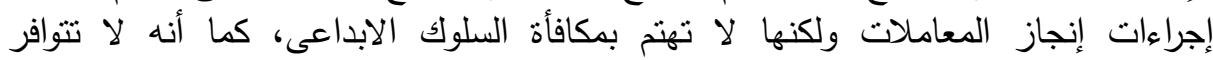

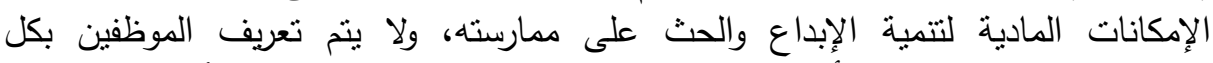

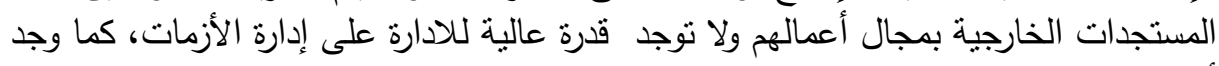

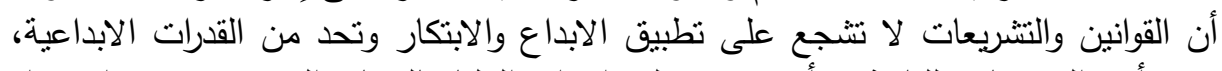

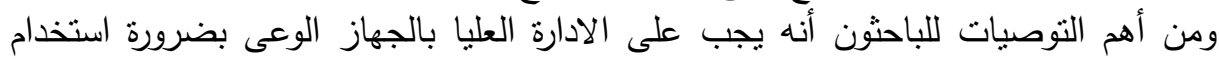

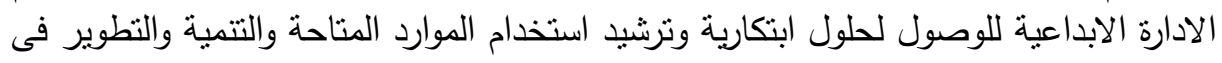

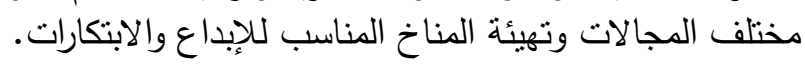
كلمات مفتاحية :الإبداع، ادارة الابداع، الإبتكار، البيئة الداخلية الإنات، البيئة الخارجية .

\section{ravall}

إن الدراسات البيئية تعد من الموضوعات الحديثة نسبياً في دراسات الإدارة، حيث كان التزكيز في الماضي على المشاكل الداخلية للمنظمات فقط، ولم يتم التركيز على البيئة. 
ولقد أجمع كتّاب الإدارة والمديرون اليوم على أن حاجة المنظمات إلى الإبداع والابتكار

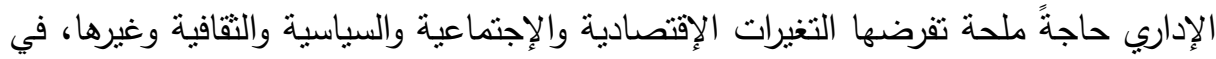

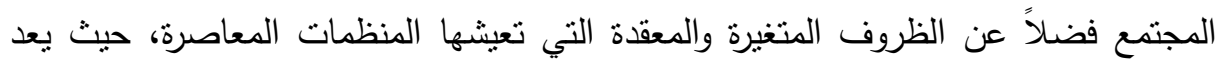
الإبداع الإداري إحدى المقومات الأساسية في عملية التطوير التنظيمي. فالتطورات التي

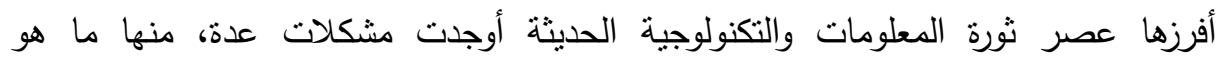

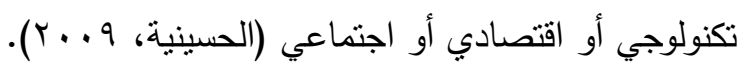
فالإبداع الإداري صاحب الاثر الكبير فى مجال التطوير الادارى(هالة عبد القادر

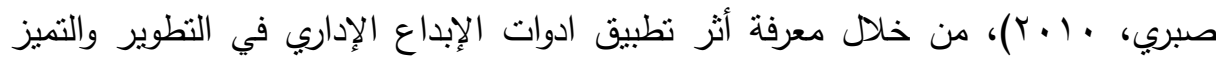

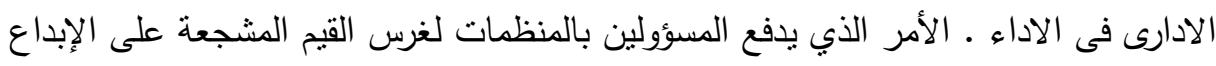

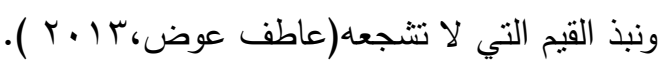

وفى عام 10 بـ، كثف المرصد المصري للعلوم والتكنولوجيا والابتكار، في تقريره

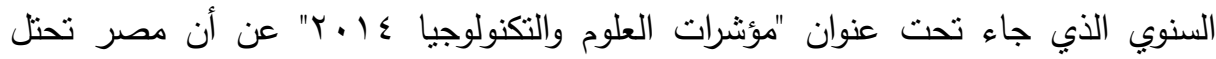

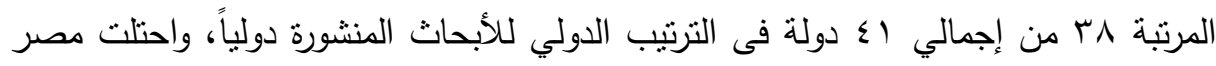

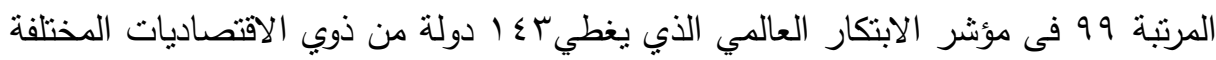

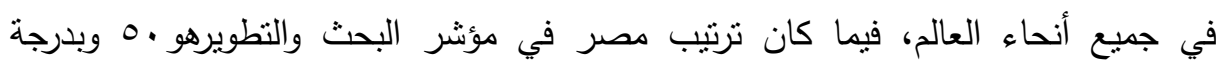

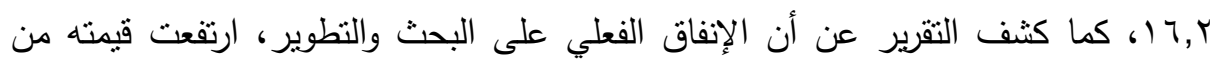

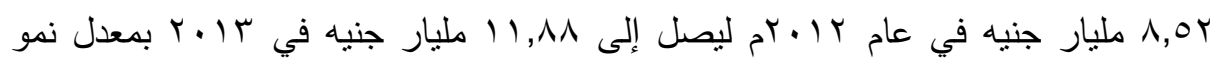
يمثل r,7 1\%. وأن نسبة الانفاق على البحث والتطوير من الناتج المحلي الإجمالي كانت

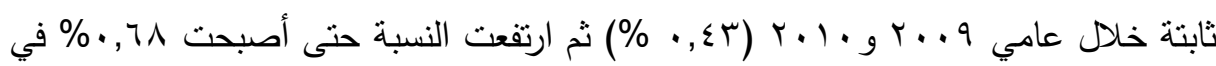

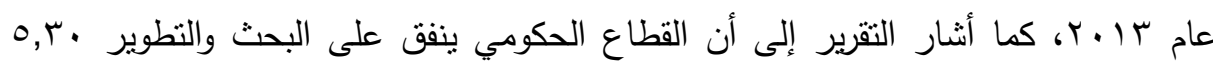

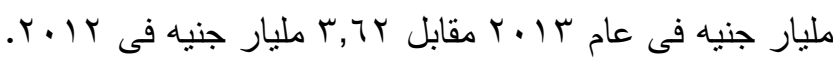


لذلك كان من المحتم على القطاع الحكومى أن يستجيب للنطورات الحديثة وإحداث التعديلات التي تواكب هذه النطورات، وتكون هذه الإستجابة عن طريق الأفكار الجديدة والأساليب الحديثة حتى يتمكن من مواجهة التحديات والمشكلات البيئية.

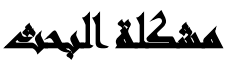

يعتبر الجهاز المركزى للتنظيم والادارة من المؤسسات الحكومية الغير هادفة للربح بل

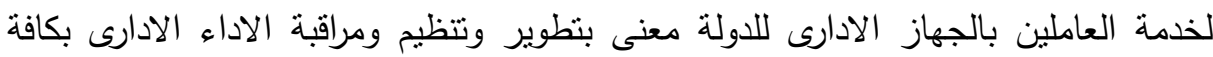

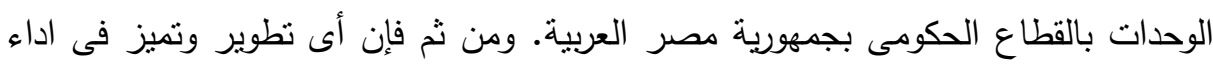
الجهاز والعاملين به ستتعكس على أداء الوحدات فى القطاع الحكومى ككل.

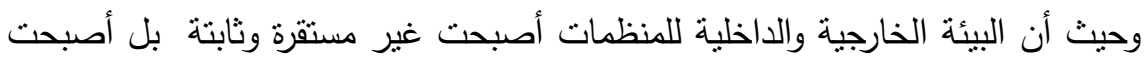
حركية وديناميكية، الأمر الذي نتج عنه العديد من المشكلات المعقدة والمتشابكة التى ألقت

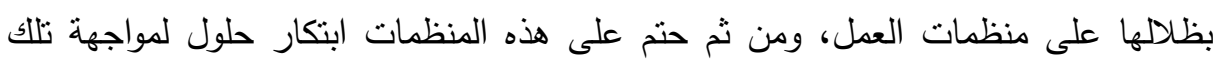

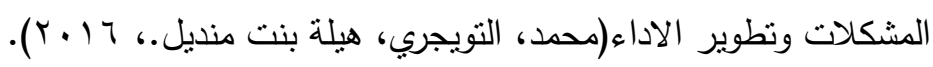

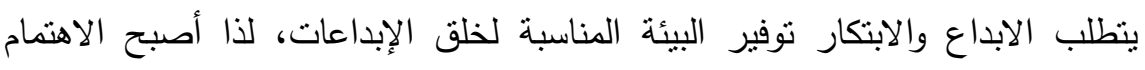

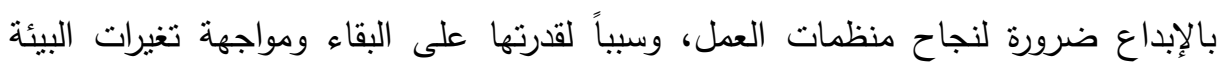
الخارجية المتلاحقة.

مما أوجب ضرورة التقكير في التقليل من الاعتماد على المنهج التقليدي القائم على هلى

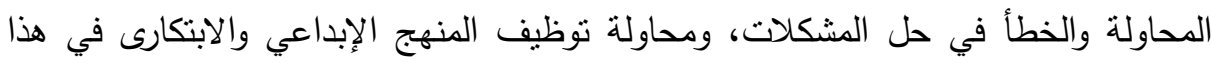

فلقد اصبح الإبداع الإداري إحدى المقومات الأساسية في عملية النطوير التنظيمي.

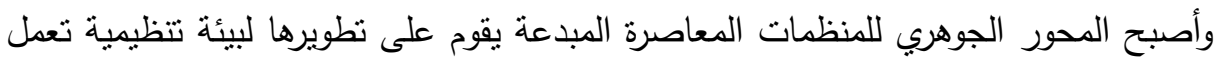

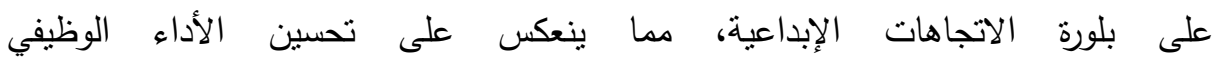

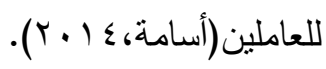

لذللك كان من الضرورى على المؤسسات الحكومية وبالأحرى الجهاز المركزى للتنظيم والادارة أن يستجيب لهذه النطورات بإحداث التعديلات التي نواكب هذه التطورات، وتكون هذه

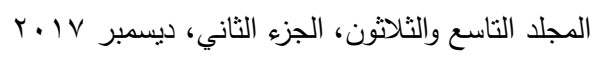


الاستجابة عن طريق الأفكار الجديدة والأساليب الحديثة التي تمكنه من مواجهة التحديات

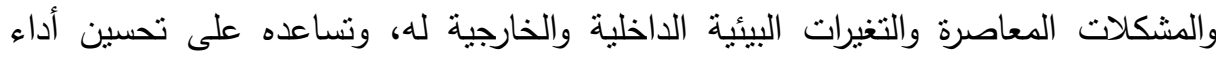
العاملين مما ينعكس على أداء القطاع الحكومى.

\section{أسهولة المهيث}

ا. ما أثز البيئة الادارية والتتظيمية للجهاز المركزى للتنظيم والادارة على استخدام ادارة

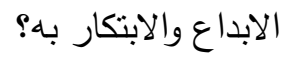

r. ما أثز البيئة الثقافية والاجتماعية للجهاز المركزى للتنظيم والادارة على استخدام ادارة

$$
\text { الابداع والابتكار به؟ ماتبه }
$$

r. ما أثز البيئة القانونية والتتريعية للجهاز المركزى للتنظيم والادارة على استخدام ادارة الابداع والابتكار به؟ اله النه

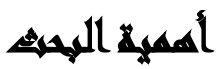

يشهر العالم اليوم تغيرات وتطورات مستمرة أدت إلى تغيير في بيئة عمل المنظمات

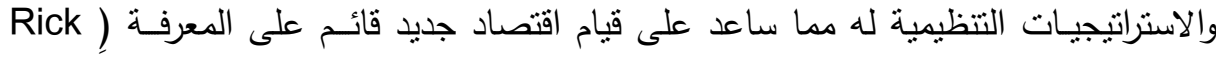
(Eagar \& others,2011)، وفي ظل هذه التحولات أصبحت المعارف والعلوم هي المصدر سئر الأهم للميزة التتافسية، مما أوجب الاهنمام البالغ بعامل الإبداع التكنولوجي باعتباره الرابط بين مستوى الموارد البشرية والمستوى المعرفي والعلمي، وهو بذللك يعكس مدى تقدم نشاطات البحث والنطوير والعمليات الإبداعية فى التفكير وحل المشكلات ووضع الاستراتيجيات (Pablo Sanchez, Joan E للمنظمات، ومسايرة التكنولوجيات والتقنيات الحديثة

.Ricart,2010)

يستقيد الجهاز المركزى للتنظيم والادارة كوحدة حكومية ذات تأثثير كبير على أداء

الوحدات الحكومية الاخرى من هذه الداسة ويقوم بالتالى بنطوير أداء باقى الوحدات

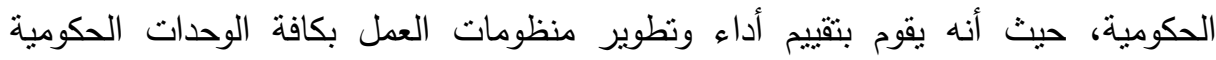
476

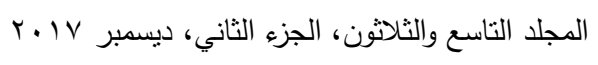


بالجهاز الادارى بجمهورية مصر العربية، وتقوم الدراسة التطبيقية على دراسة الوضع القائم

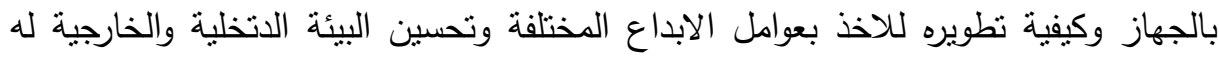
لتساير الابداع، كما أن الدراسة نساهم فى نوعية المديرين بالجهاز من خلال بيان اهمية

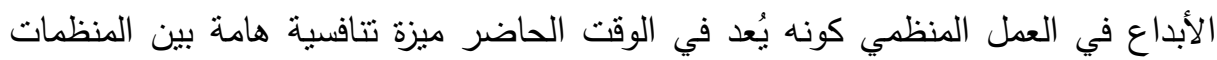
ومدى مساهمه ذلك في تحقيق الأداء المتميز سواء على مستوى الأفراد أو المنظمة.

\section{أهفاهيخ المهيث}

يهدف البحث الى دراسة البيئة الداخلية والخارجية للجهاز المركزى للتنظيم والادارة كوحدة حكومية مهثلة للوحدات الحكومية التى تقدم خدمات للقطاع الحكومى والعاملين به، وذللك للوقوف على العوامل المعوقة وكذللك المعضدة لإستخدام ادارة الابداع والابتكار بهدف تحسين الاداء، حيث أن الاتجاه فى الدراسات الادارية الحديثة الآن هو البحث عن رضا المستفيدين

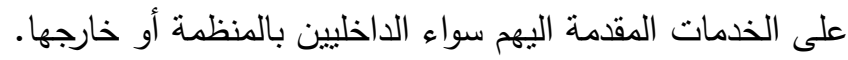

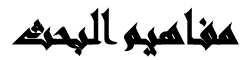

المناخ التنظيمي: هو مجموعة الخصائص والمميزات التي تميز بيئة العمل الداخلية للمنظمة، والتي يمكن إدراكها واستقرائها من خلال الطريقة التي تتعامل بها المنظمة مع بيئتها

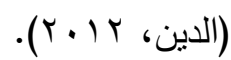
مفهوم الإبداع الإداري: مفهوم الإبداع الإداري واسع وله أبعاد مختلفة تتعلق بالتغيير في البيئة الاجتماعية والاقتصادية للمؤسسة كما تتمل التغير في سلوك الأفراد العاملين واستخدام

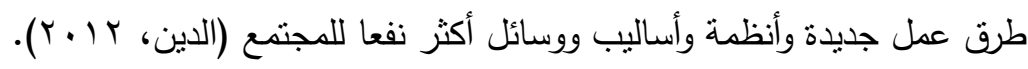
المنظمات الابداعية: هى المنظمات التى تتبع الاساليب الابداعية فى أداءها لاعمالها وتحفز وتتمى الانشطة الابداعية لدى الافراد وتوليها التزامات مالية وتدريبية ومعرفية كبيرة .(Lina Girdauskiene ,2012) 
معوقات الإبداع: هى العوامل التي تؤثر بشكل سلبي على العملية الإبداعية بالمنظمات

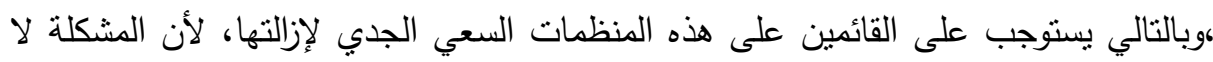

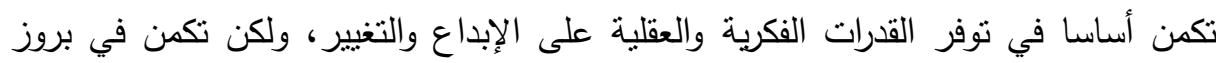
المعوقات التي تحد من نلأك القدرات(حلمي، 7 ( • ب).

\section{السراسايت السابرية}

ا - منذر العكور(7 1 • r): تهدف الدراسة إلى التعرف على الثقافة التتظيمية فى تحقيق الإبداع الإدارى لدى العاملين فى وزارة الداخلية الأردنية، إستخدم الباحث الإسنتبانة لجمع البيانات وتحليلها إحصائيا، وإفترضت الدراسة وجود أثز ذو دلالة إحصائية للتقافة

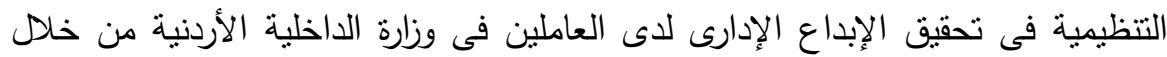
عناصرالإبداع (الطلاقة والأصالة ) ومن نتائج البحث أنه يوجد أثز ذو دالإدئ دلالة إحصائية للانقافة التنظيمية فى تحقيق الإبداع الإدارى( الطلاقة والأصالة والإقناع للعاملين ). r - منار أحمد منصور( ( 1 • r): تهدف الدراسة الى تحديد العلاقة بين قيم العمل والإبداع الإدارى لدى الإداريين بجامعة الطائف ومدى توافر عناصر الإبداع الإدارى وما إذا إختلف الإبداع الإدارى بإختلاف سنوات الخبرة والتخصص والمؤهل العلمى. وتكونت

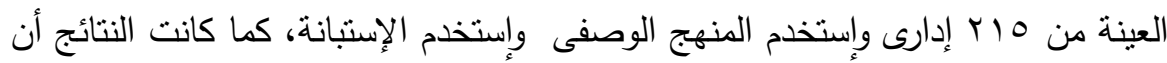

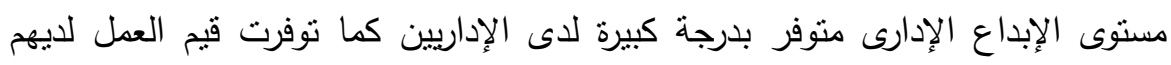

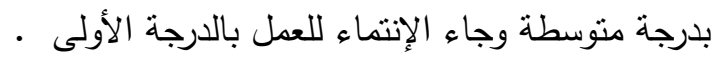
r-Fredricka K. Reisman (2014) تبرز هذه الدراسة أهمية الإبداع في التعليم والأوساط الصناعية والحاجة إلى تحسين الإبداع، كما تعرض أيضا استراتيجيات محددة لتعزيز الإبداع الفردى والابداع فى الثركات وإمكانية نطبيق الإبداع فى الساحة التجارية. وأنه من الأهمية تسليط الضوء على الدور الحيوي الذي تؤديه القيادات الإبداعية في تتشيط الابتكارات، وتتتاول المؤشرات الرئيسية التالية للتفرقة بين الادارة التقليدية والادارة

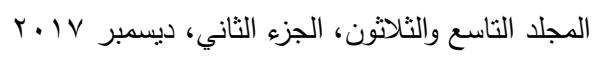


الابداعية السلطة، المعلومات، نوليد الافكار ، حل المشكلات، تخصيص الموارد، القوانين والمسؤوليات، حل المشكلات من جذورها والاداء والتغذية المرتدة.

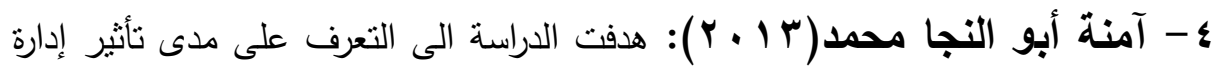
نقاط قوة العاملين على الإبداع الإداري، وقد تم تجميع بيانات الدراسة من استقصاء آراء عينة من العاملين البنوك. وشملت عينة الدراسة إب من العاملين بالبنوك التجارية الرداية بمحافظة الغربية، بلغ عددها البنوك- |N1 بنكا، وقد نم اختبار فرضيات الدراسة باستخدام تحليل الانحدار المتعدد وتحليل التباين وانصب اهنمام الدراسة على تحليل نأثير

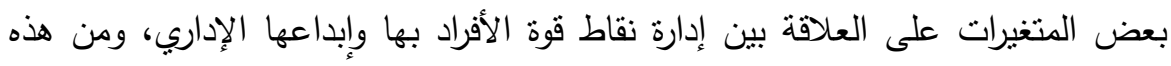

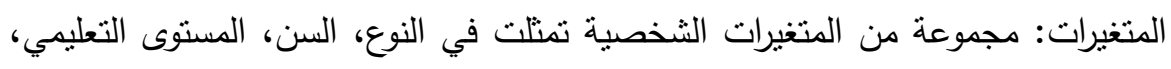
وبعض المتغيرات الوظيفية، متضمنة عدد سنوات الخبرة والمستوى الإداري وعدد الدورات

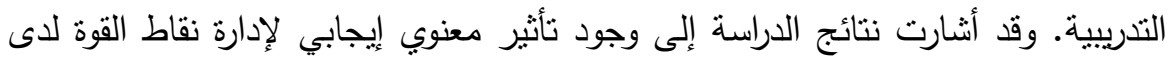

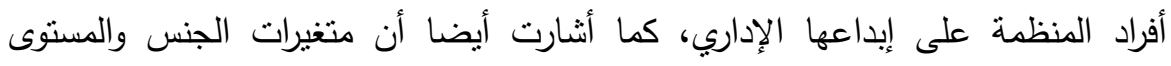

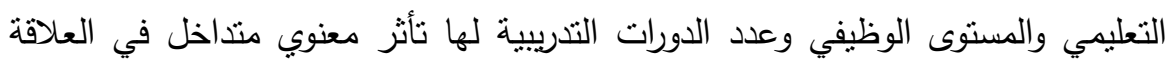
بين إدارة نقاط قوة العاملين والإبداع الإداري. ه - عاطف عوض(ب ا • Y): هدفت هذه الدراسة إلى معرفة واقع الإبداع الإداري في

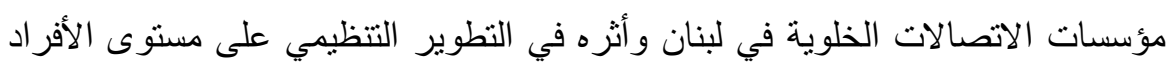

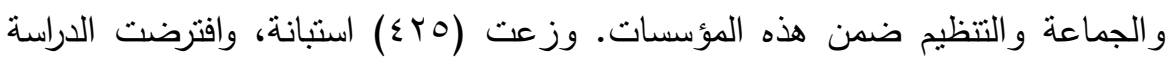
وجود علاقة ذات دلالة احصائية بين الابداع الادارى (للفرد والجماعة والتنظيم) والتطوير

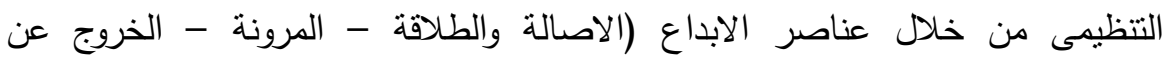

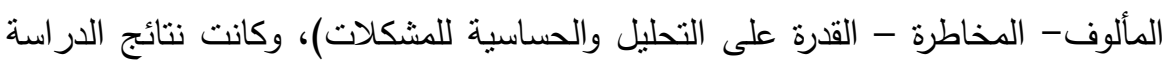

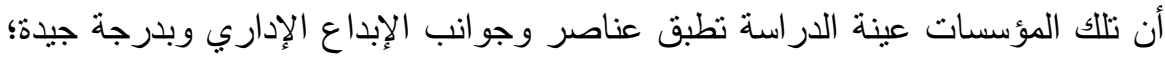
مما يؤثر إيجابياً في النطوير التنظيمي على المستويات جميعها.

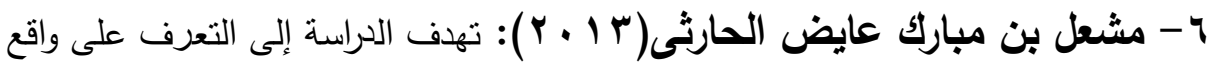
تطبيق عناصر الإبداع الإداري لدى مديري المدارس الثانوية.

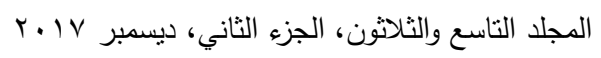


والتعرف على المعوقات التتيظيمية الثخصية والمعوقات التقافية والاجتماعية للإبداع الإداري لاى مديري المدارس الثانوية والفروق ذات الدلالة الإحصائية والكثف عن مدى ولى تو افر عناصر الإبداع الإداري لدى مديري المدارس الثانوية، استخدم الباحث المنهج الوصفي

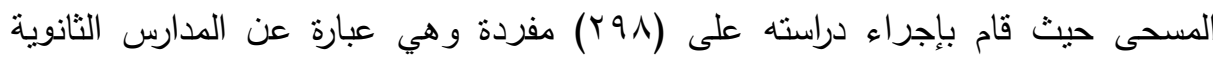
الحكومية فى محافظة جدة.

ولقد قام الباحث بتصميم استبانة نتنمل على أربعة محاور لواقع تطبيق عناصر الإبداع الإداري لمديري المدارس الثانوية منها المعوقات التنظيمية والثخصية والاجتماعية والثقافية.

وكانت أهم نتائج الدراسة نوافر عناصر الإبداع الإداري بدرجة كبيرة وكان واقع تطبيق

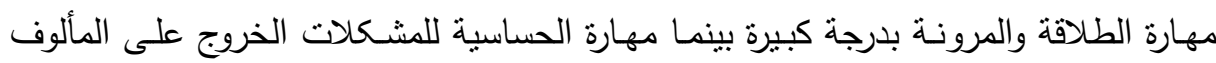
بدرجة منخفضة وبقية المهارات بدرجة متوسطة وكانت المعوقات التنظيمية بدرجة كبيرة.

\section{الإطاار المظلريى اللهيهث}

أولاً: مفهوم الإبداع والإبتكار: اختلفت الآراء حول مصطلح الإبداع والإبتكار وبعض

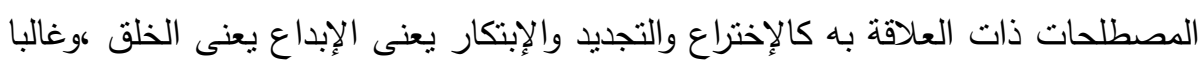

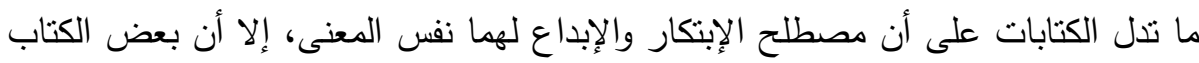

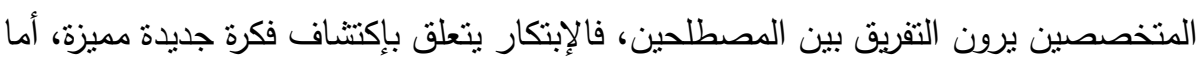

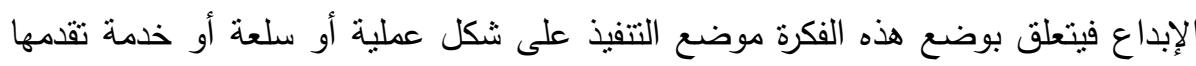
المنظمة لعملائها.

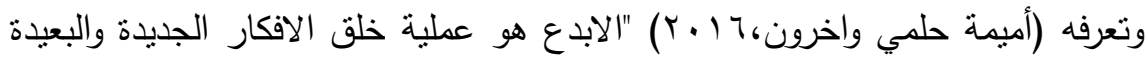
عن السياق التقليدى فى التفكير واستخدام كافة الطرق والأساليب التى من شأنها تحويل هذه الهانه الافكار الى واقع مطبق وذو قيمة نافعة" 
الابداع يتطلب القدرة على انتاج مخرجات جديدة بجودة عالية ومناسبة للهدف المطلوب، وهى ايجاد افكار جديدة لمنتجات وخدمات ذات قيمة عالية ووحيدة فى السوق( ) David H. - (Cropley, James C. Kaufman, Arthur J. cropley,2011 ويرى الباحث أن أثنمل تعريف للإبداع هو " الإبداع طاقة عقلية هائلة، إجتماعية في

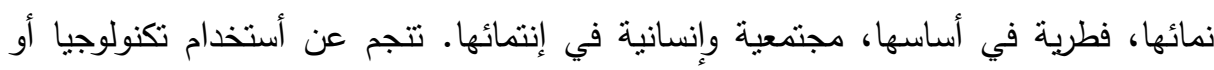

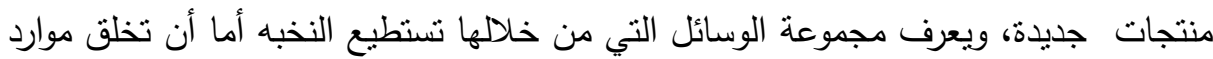
جديدة مدره للثروة أو تطوير الموارد الحاليه لجعلها من المككن أن تكون مصدرا للثروة".

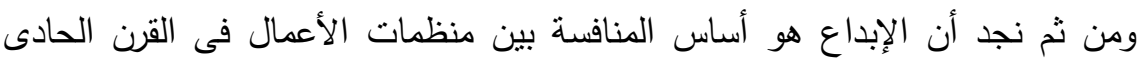

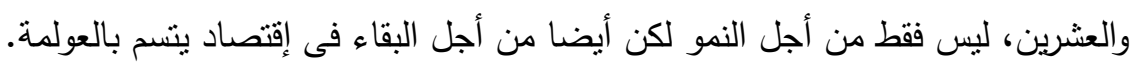

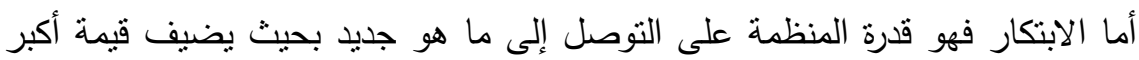

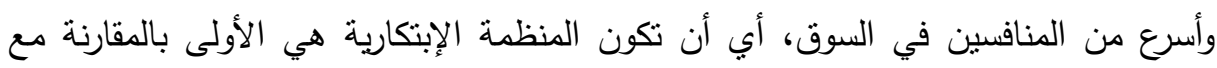
المنافسين في التوصل إلى الفكرة الجديدة أو المفهوم الجديد أو المنتج الجديد. ثانيا: عناصرالأبداع والإبتكار ا.القرة على التخطيط والتفكير الإستراتيجي: من خلال وضع الخطط المستقبلية للنطور

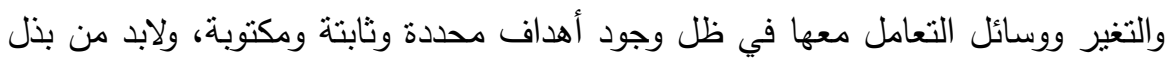

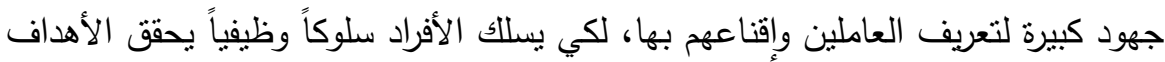
والخطط المرسومة. r.بناء ثقافة تنظيمية: تمثل الثقافة التنظيمية الموروث الحضاري والقيمي للمنظمة الذي يحكم تصرفات وسلوكيات الأفراد ومواقفهم تجاه القضايا الإدارية والعملية المختلفة، ولها دور العهاء كبير في التأثير على سلوكيات الأفراد وإتجاهات المنظمة وصياغة الإستراتيجيات والخطط الإدارية.

r.التركيز على الأداء والعاملين: حيث أن المنظمات المبدعة تتميز بتركيزها على الأداء وأهتمامها بالعاملين وإثعارهم بأهميتهم وأنه لايمكن الإستغناء عن جهودهم وأنهم جزء هام الماء

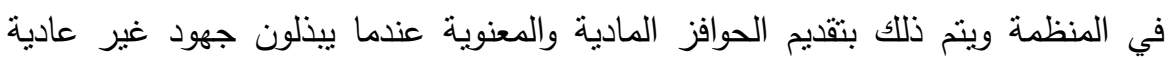

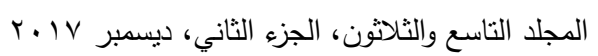


ويتصفون بأداء متميز وإنتاجية عالية. وذللك من أجل الإهنمام بالإنتاج النهائي ومعدلات الأداء وكذللك الإهتمام بكيفية هذا الأداء ونوعه مما يساعد على المساهمة في إطلاق الطاقات الكامنة لدى العاملين ويشجع على الإبداع.

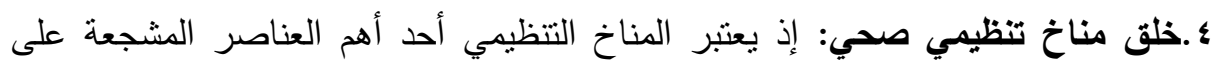

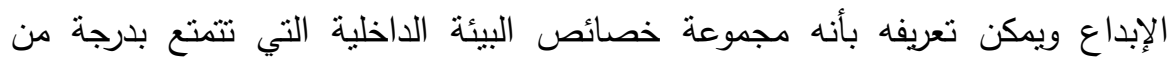

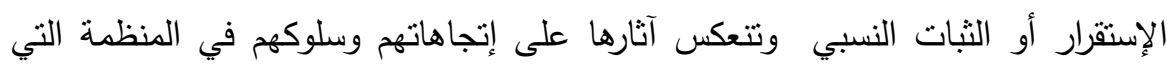
يعملون بها.

ه.مرونة الأنظمة والللائح :إن مرونة الأنظمة واللوائح عنصر مهم من عناصر المنظمة

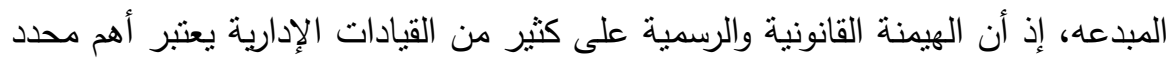

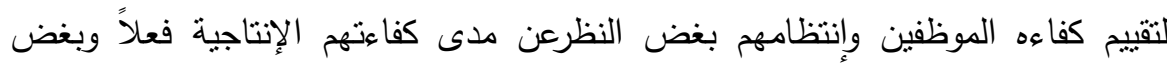
النظر عن مدى قدراتهم الإبداعية.

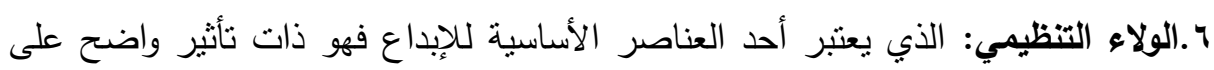
الأداء وعلى إنتاجية المنظمات وتحسين الأداء وزيادة الإنتاجية وتتجيع الأبداع. لأبئ. ثالثاً: أهمية تبنى ادارة الابداع والابتكار بالمنظمات: هناك اتفاق واسع النطاق على الثى أن الإبداع يتطلب القدرة على تحقيق نتائج جديدة، ذات جودة عالية ومناسبة للغرض منها (نمو وتميز وتتافس) ويمكن أن تشمل هذه النتائج المنتجات والخدمات والأفكار والعمليات أو دات الإجراءات التي من شأنها أن نكون فريدة من نوعها وقيمتها في أسواقها وهى عملية توليد فرص عمل جديدة، سواء كان ذلك في شكل منتج أو عملية، أو نظام او خدمة. وحيث ان الابداع "هو تطوير الأفكار، في حين الإبتكار هو تطبيق الأفكار " فانه

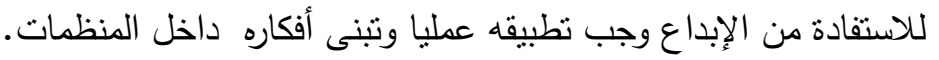




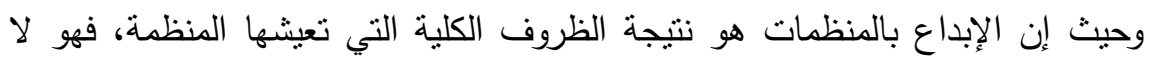

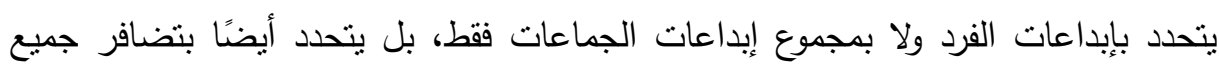

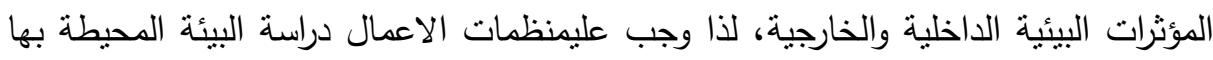
سواء داخلية وخارجية والتعرف على امكاناتها وقيودها المؤثرة على أداء أعمال المنظمات.

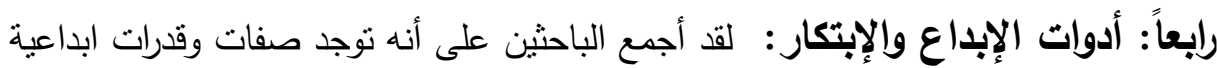
تميز كل من الفرد والجماعة والمنظمة ويمكن تقسيمها إلى: أ. مهارات مرتبطة بالفرد أو الجماعة بالمنظمة، حيث أن المباع هو من يمتلك عنداصر

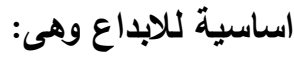
ا ـ الأصالة : وهى القدرة على انتاج أفكار أقل تكرارا وشيوعا ويجب أن تخدم الفكرة الهدف

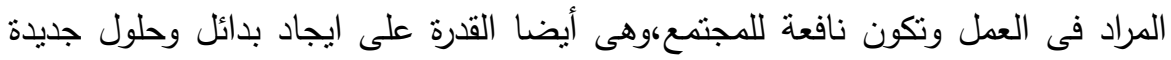

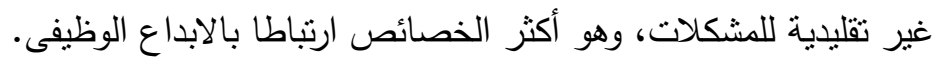

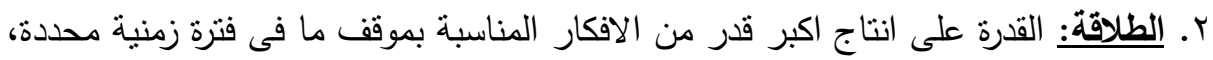
وهو سرعة استدعاء الافكار لمواجهة موضوع معين خلال فترة زمنية محددة.

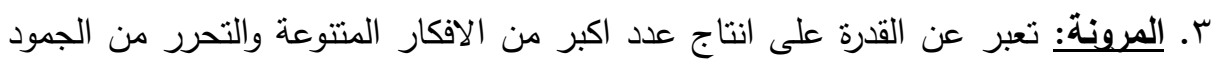

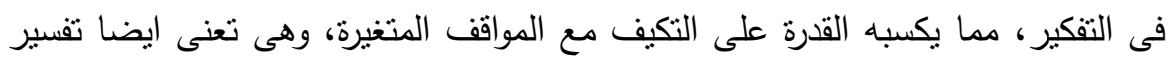
جديد للهدف او تغيير فى استراتيجية او طريقة المقاربة او تغييرات فى الحلول الممكنة.

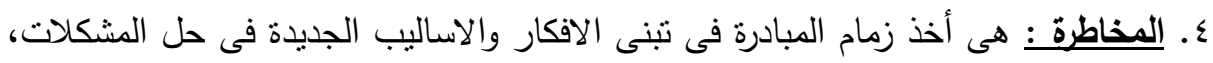

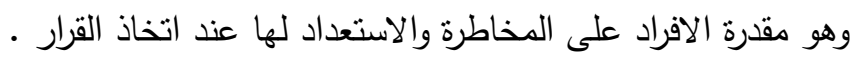
0. الحساسية تجاه المشكلات: وهوقدرة الفرد بالمنظمة على التنبؤ بالمشكلات ورصدها وها مبكرا

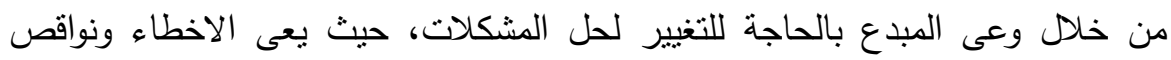

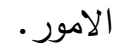




\section{ب. مهارات وقدرات ابداعية لدى المنظمة: وتتمنل فى التالى:}

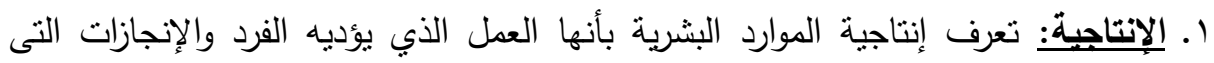
يحققها ومدى مقابلة الأداء للمعايير الموضوعة وطرق التحسين والتطوير التى يمكن للفرد سلوكها ليزيد كفاءة الأداء ورغبة الفرد فى أداء عمله بصورة متميزة. r. تشجيع الأفراد والتعاون بينهيد: مراعاة الجوانب السلوكية من خلاءل حاجات الأفراد

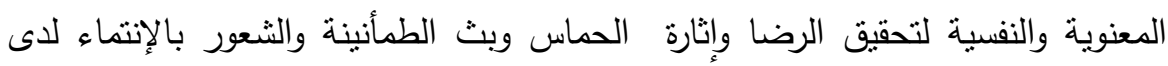
الأفراد والتتجيع على الإبداع والتطوير فى مجال العمل مع التأكيد على أهمية التعاون

$$
\text { والمشاركة. }
$$

r. تظوير الأداء للوصول إلى الآداء المتمبز: هو المحور الرئيسي الذى تدور حوله عملية التتمية فى المجتمع فهو أداة التتمية ووسيلتها، يعد الهدف الرئيسى من اي تطوير للآداء

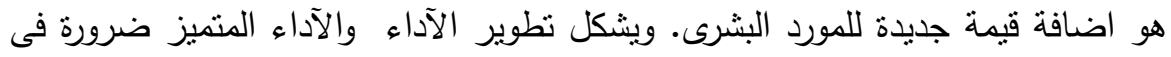
عصر تتطور فيه المعارف والمعلومات والتقنيات بصورة سريعة، حيث يقوم التدريب والتتمية بسد الفجوة فى أداء العاملين مما يرفع من أداء المنظمة ككل ويساعدها على ولى ولى الإبداع والإبتكار ، حتى تسنطيع أن تجابه حاجات المجتمع المتزايدة.

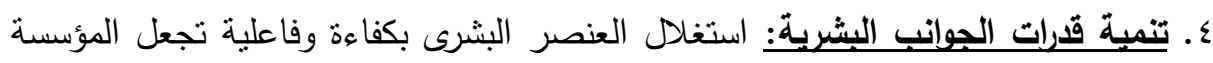

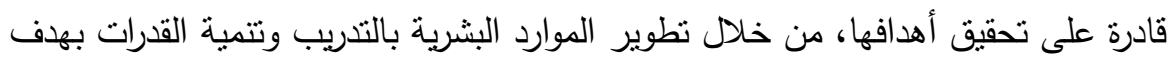
تحسين أداءهم للأعمال واكتساب المعارف والمهارات وصقل القدرات المؤهلة للإبداع والإبتكار مع توفير الأدوات والوسائل والظروف المشجعة على تحسين وتطوير الأداء حتى لهى

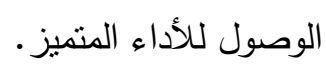

ه. تبني التغيير واستخدام طق وأسالب حدبثة: ينمثل الإبداع في القدرة على إبتكار الأساليب التي من خلالها يمكن التجاوب مع العاملين وحثهم على استثمار قدراتهم ومواهبهم داخل المنظمة، كذلك تنبي التغيير واستخدام طرق وأساليب حديثة في مجال العمل وصولا إلى تحقيق الأهداف المشتركة. 
خامساً: معوقات الإبداع والإبتكار الإداري: هى العقبات والصعوبات البيئية داخل

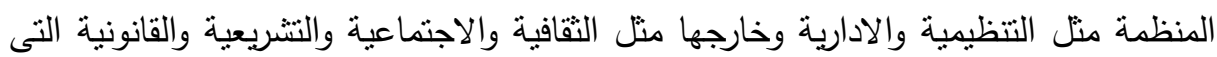

$$
\text { تحد من الإبداع فى المنظمة، وهى كالتالى: }
$$

ا.معوقات الإبداع داخل نطاق الفرد: حيث تثمثل المعوقات الفردية في الخوف من الفثل والتمسك بالعادات والتقاليد المألوفة والتبلد الذهني والتخصص الضيق أو المحدود والناحية الإنفعالية والإدراك الثخصي والعامل الإجتماعي والإلتزام بنمط معين لحل المشكلات وغياب القدرة على التصور والتخوف من التحدي ومواجهة المجهول وغياب جو الحرية وغياب الدوافع الداخلية للإبداع والخوف من الظهور وتقديم حلول جديدة

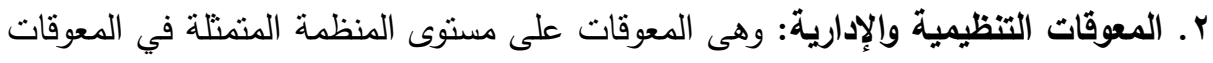

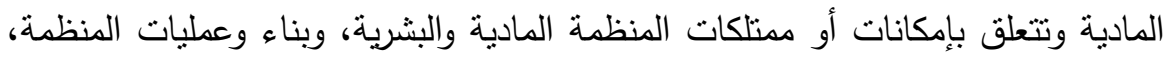
والمعوقات التقافية التى تشير الى القيم الموجودة داخل المنظمة المتعلقة بالتشجيع أو إعاقة الإبداع وقبول التغيير او قبول الحل الظاهري للمشاكل والحكم السريع على الأفكار

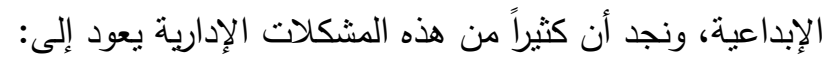
أ. عدم وضوح الأهداف للمنظمة. ب. المركزية والتسلط. ج. الإفتقار إلى معايير واضحة للألداء. د. عدم وجود اتصال فاعل. هـ الإقتقار إلى العمل الجماعي و ـ هيمنة المديرين المفتقرين للمعرفة والمهارة الإدارية على المنظمات. ز ز عدم وجود حوافز مادية ومعنوية لأصحاب الأفكار الإبداعية. ح. عدم وجود البرامج التدريبية التي تساعد على تتمية المهارات الإبداعية.

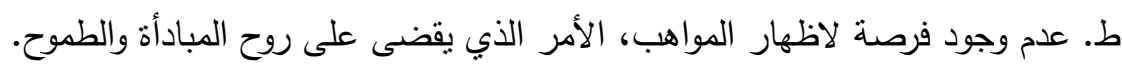


r. المعوقات الإجتماعية والثقافية: أما المعوقات الإجتماعية والثقافية فتتمثل فى البيئة الخارجية للمنظمة من حيث المتغيرات البيئية والعادات والتقاليد والقيم الإجتماعية التى الإهي تعوق كل من الإبداع الفردى والإبداع على مستوى المنظمة.

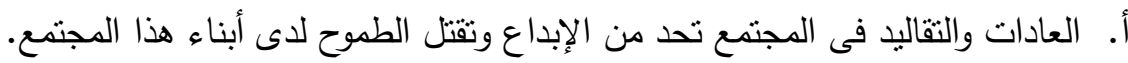

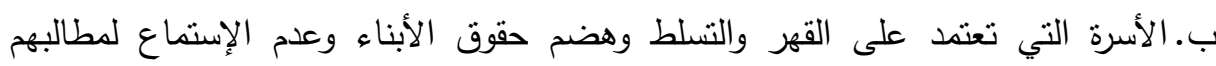
والتقليل من شأنهم سيكون لها دور رئيسي في الحد من الإبداع لدى أبنائها.

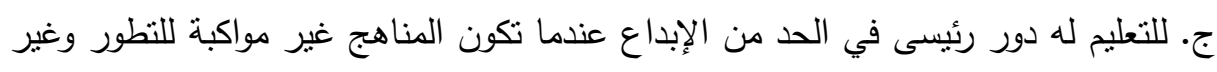
مشجعة على التفكير الإبداعى والابتكارى. ـ -القوانين والتشريعات: التشريعات والقوانين الملزمة للمؤسسات قد تكون غير مواكبة للنطور وغير مشجعة على التفكير الإبداعى والابتكارى.

\section{إجباءاهي وطرة الهمهي}

بناءاً على طبيعة الدراسة والأهداف التي تسعى الى تحقيقها فقد تم استخدام المنهج

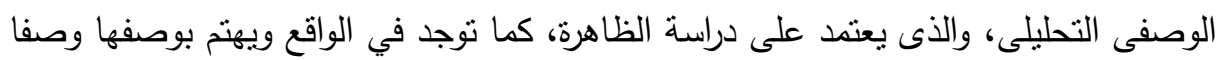
دقيقا ويعبر عنها تعبيرا كيفيا وكميا، كما لا يكتفى هذا المنهج عند جمع المعلومات المتعلقة بالظاهرة من اجل استقصاء مظاهرها وعلاقاتها المختلفة، بل يتعداه الى التحليل والربط والتفسير للوصول الى استتناجات يينى عليها التصور المقترح بحيث يزيد بها رصيد المعرفة بهنة بهنهاه عن الموضوع، ولقد استخدم الباحث مصدرين أساسين للمعلومات: 1- المصادر الثانوية حيث اتجه الباحث في معالجة الإطار النظري للبحث إلي مصادر

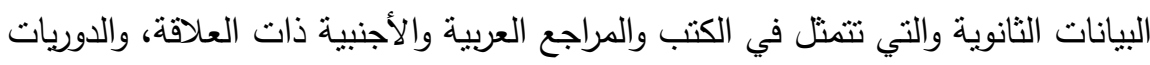
والمقالات، والأبحاث والدراسات السابقة التي تتاولت موضوع الدارسة، والبحث والمطالعة

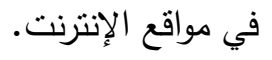


r- المصادر الأولية: لمعالجة الجوانب التحليلية لموضوع الدراسة لجأ الباحث إلي جمع

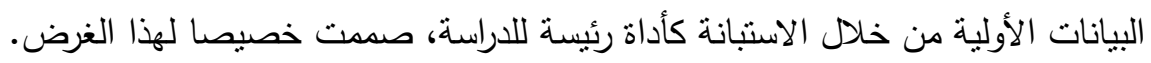

\section{منهمج المهيه}

في ضوء أهداف البحث، والأسئلة التي تحاول الإجابة عليها يقوم الباحث بنطبيق المنهج

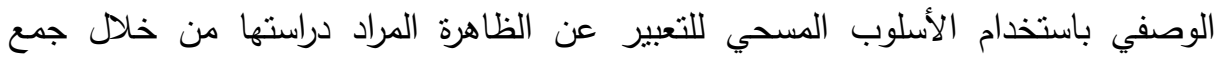

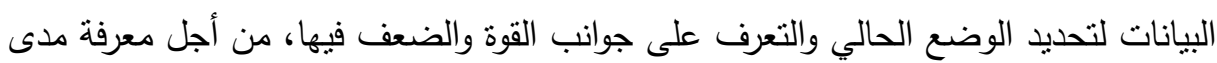
صلاحية الوضع أو الحاجة لإحداث تغييرات فيه. واستخدام المنهج الاستقرائي المكتبي بالاطلاع على المراجع حول موضوع الدراسة للتوصل إلى منطلبات إدارة الابداع والإبتكار وعلاقتها بالبيئة الداخلية والخارجية.

\section{هروغ الهميث}

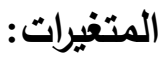

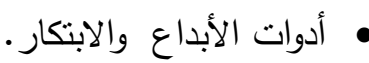

• • البيئة الداخلية ( بيئة ادارية - بيئة تنظيمية)

• البيئة الخارجية (بيئة اجتماعية وثقافية - بيئة تشريعية وقانونية )

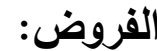

• ل لا توجد علاقة معنوية بين البيئة الداخلية(الادارية والتتظيمية) للجهاز المركزى للتنظيم والادارة وبين استخدام ادارة الابداع والابتكار به. • لا توجد علاقة معنوية بين البيئة الخارجية (التقافية والاجتماعية والتتريعية والقانونية) للجهاز المركزى للتنظيم والادارة وبين استخدام ادارة الابداع والابتكار به. 


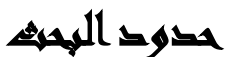

الحد الموضوعى: اقتصر البحث على التعرف على مدى تأثير البيئة الداخلية من حيث

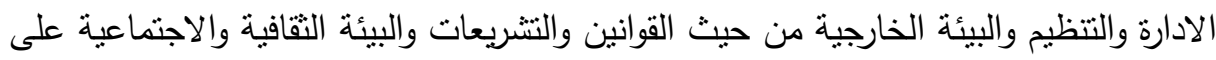
الابداع لدى العاملين بالجهاز المركزى للتنظيم والادارة. الحد المكانى: تمت الدراسة على العاملين بالجهاز المركزى للتنظيم والادارة كوحدة حكومية.

\section{مجتمع الدراسمة والعينية}

مجتمع الاراسة: بعرف بأنه جميع مفردات الظاهرة التي يدرسها الباحثون، وبذلك فان

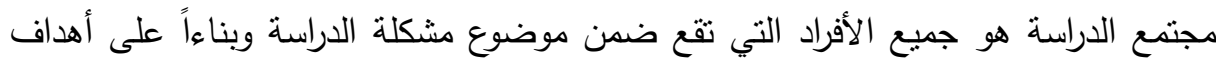
الدراسة تم تحديد المجتمع المستهدف من العاملين بالجهاز المركزى للنتظيم والادارة واستخدام اسلوب العينات العشوائية الطبقية الحكمية من كل مستوى ادارى وفقا لنسب الاعداد فى مجتمع

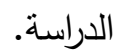
عينة الدراسةة قام الباحث باستخدام طريقة العينة العشوائية الحكمية الطبقية، حيث تم توزيع

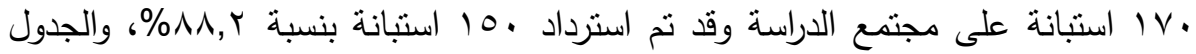
التالي يبين نوزيع عينة الدراسة:

\begin{tabular}{|c|c|c|}
\hline النسبة & العدد العدا & المستوى التنظيمى \\
\hline $1 \varepsilon$ & YI & ادارة عليا \\
\hline $0 \cdot, \mathrm{V}$ & $V T$ & ادارة وسطي \\
\hline$\Gamma, \mu$ & or & ادارة تتفيذية \\
\hline $1 \ldots$ & 10. & الاجمالي \\
\hline
\end{tabular}

أداة الدراسة: نم إعداد استبانة حول " الاثر البيئى لاستخدام ادارة الابداع "- بالتطبيق على الـى

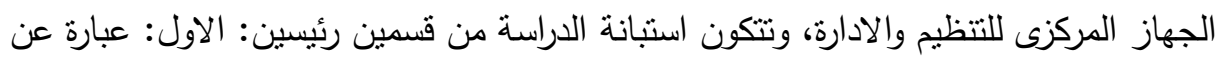
معلومات عامة عن المستجيب مثل: ( العمر - المؤهل - المستوى الوظيفى - الخبرة العملية) والثانى وهو عبارة عن محور "الامكانات والمعوقات البيئية للابداع والابتكار بالجهاز 488

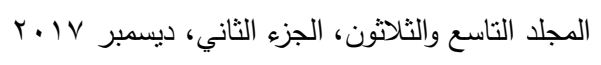


المركزى للتنظيم والادارة" ويتضمن 17 فقرة،وتم استخدام مقياس ليكرت الخماسي لقياس استجابات المبحوثين لفقرات الاستبيان. قام الباحث باستخدام الأدوات الإحصائية التالية: 1. اختبار ألفا كرونباخ: وذلك لمعرفة ثبات فقرات الادوات الإستبانة. r. اختباركولمجوروف- سمرنوف: لمعرفة إذا كانت البيانات تتبع التوزيع الطبيعي من عدمه. r. معامل ارتباط بيرسون: لقياس درجة الارتباط والاتساق الداخلي والصدق البنائي للاستبانة. ع. النسب المئوية والتكرارات: لوصف عبئن عينة الدراسة وتحديد استجاباتهم. ه. المتوسط الحسابي لتحديد الترتيب والاهمية النسبية لاستجابات الافراد داخل عينة الدراسة. T. اختبار T-Test في حالة عينة واحدة للتأكد من دلالة المتوسط لكل فقرات الاستبانة. أولا: اختبارات صدق الاستبانة: 1- الصدق البنائي Structure Validity: يعتبر الصدق البنائي أحد مقاييس صدق الأداة الذي يقيس مدى تحقق الأهداف التي تريد الأداة الوصول اليها، ويبين مدي ارتباط لهين كل محور من مجالات الدراسة بالدرجة الكمية لفقرات الإستبانة. جدول(ץ): يوضح معامل الارتباط بين كل فقرة من فقرات المحور " الامكانات والمعوقات البيئية

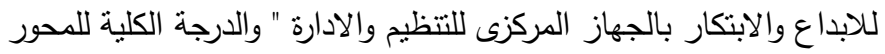


مجلة العلوم البيئية

معهز الدراسات والبحوث البيئية - جامعة عين شمس لهن

\begin{tabular}{|c|c|c|}
\hline القِيمة الاحتمالية & بعامل الاربتباط & الفقرات \\
\hline$\cdot, \cdots$ & ., & 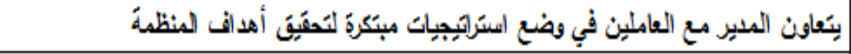 \\
\hline$\cdot, \cdots$ & $\cdot,\{\wedge \mu * *$ & 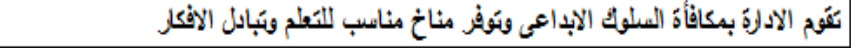 \\
\hline$\cdot, \cdots$ & $\cdot, £ ৭ \&$ \# & 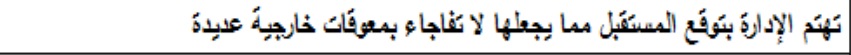 \\
\hline$\cdot, \cdots$ & $\cdot, \wedge_{1}^{*} *$ & 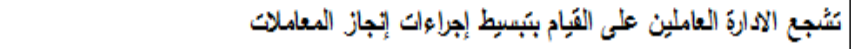 \\
\hline$\cdot, \cdots$ & •, & 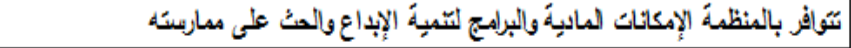 \\
\hline$\cdot, \cdots$ & , & 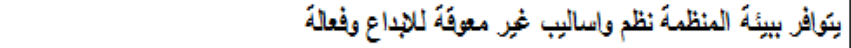 \\
\hline$\cdot, \cdots$ & $\cdot, \triangle \wedge V * *$ & 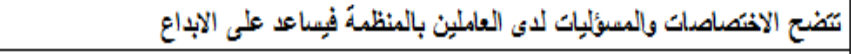 \\
\hline$\cdot, \cdots$ & $\cdot, V \times\{* \#$ & 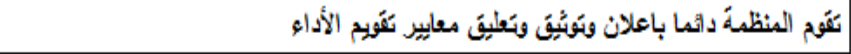 \\
\hline$\cdot, \cdots$ & $\cdot, 11, * *$ & 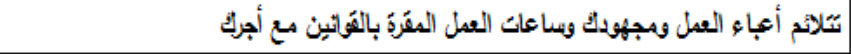 \\
\hline$\cdot, \cdots$ & $\cdot, 1 \leqslant \% *$ & 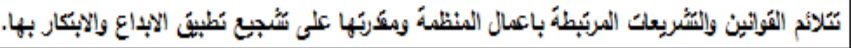 \\
\hline$\cdot, \cdots$ & $\cdot, 170 * *$ & 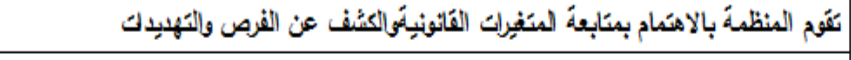 \\
\hline$\cdot, \cdots$ &, $7 \vee \leqslant * *$ & 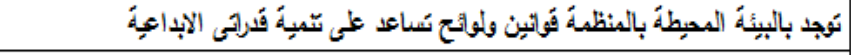 \\
\hline$\cdot, \cdots$ & $\cdot,+1+1 * *$ & 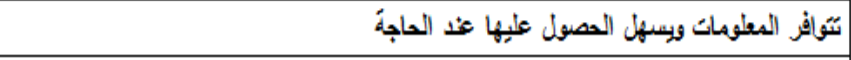 \\
\hline$\cdot, \cdots$ & $\cdot, \mathrm{V} \varepsilon, *$ & تثلاثم الدورات التكريبية والمعارفت المتاحة للمنظمة ميع تخصص العاملِين الموظِيفي. \\
\hline$\cdot, \cdots$ & $\cdot, \mathrm{Vl}, * *$ & 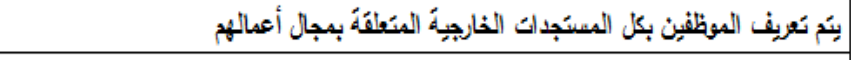 \\
\hline$\cdot, \cdots$ & $\cdot, \mathrm{Vr}, * *$ & 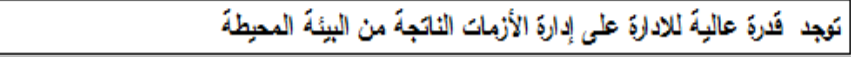 \\
\hline
\end{tabular}

يبين الجدول أن معاملات الارتباط المبينة بكل عنصر دالة عند مستوب معنوبة ه 0. , • وبذللك يعتبر المحور صادق لما وضع لقياسه. r - ثبات الاستبانة Reliability: ثبات الاستبانة بعني الاستقرار في نتائج الاسنبانة وعدم تغيرها بشكل كبير فيما لو تم إعادة توزيعيا على الأفراد عدة مرات خلال فترات زمنية معينة.وقد تحقق الباحث من ثبات استبانة الدراسة من خلال: معامل ألفا كرونباخ Cronbach's Alpha Coefficient جدول رقم(ب): يبين معامل ألفا كرونباخ Cronbach's Alpha Coefficient، لقياس ثبات الاستبانة

المحاور


محمود محمد صبح وآخرون

\begin{tabular}{|c|c|c|c|}
\hline الأ|تى * & كرونباخ & الفقرات & \\
\hline$\cdot, 97 \leqslant r$ & • , १९. & 17 & 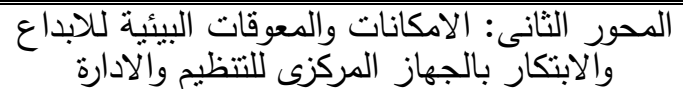 \\
\hline
\end{tabular}

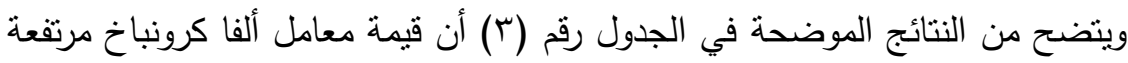

وكذلك قيمة الصدق الذاتي مرتفعة وهذا يعنى أن الثبات مرتفع ودال إحصائيا.

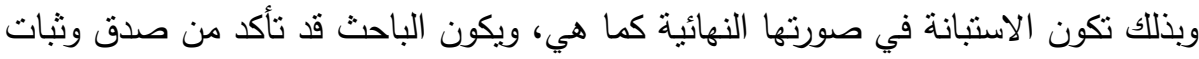

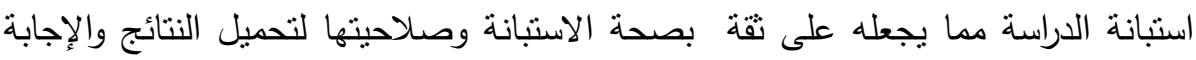

على أسئلة الدراسة واختبار فرضياتها.

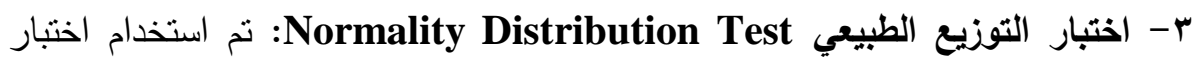

كولمجوروف - سمرنوف (Kolmogorov-Smirnov Test K-S) لاختبار ما إذا كانت

البيانات تتبع التوزيع الطبيعي من عدمه، وكانت النتائج كما هي مبينة في جدول التالى: 
جدول رقم(؛) ): اختبار كولمجوروف سمرنوف لاختبارإذا كانت البيانات ذات نوزيع طبيعي.

\begin{tabular}{|c|c|}
\hline القيمة الاحتمالية & 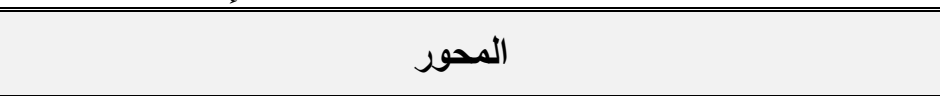 \\
\hline$\cdot, \wedge \mu \wedge$ & الامكانات والمعوقات البيئية للابداع والابتكار بالجهاز المركزى للتنظيم والادارة \\
\hline
\end{tabular}

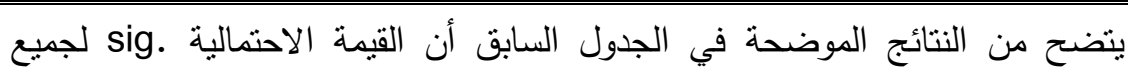

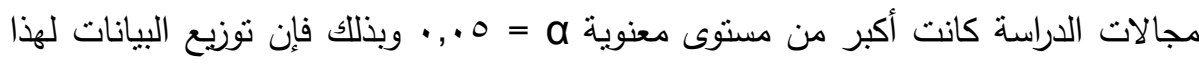
المجال يتبع التوزيع الطبيعي.

ثانياً: التحليل الإحصائي الوصفي للمتغيرات: استخدم الباحث إسلوب التحليل الوصفي

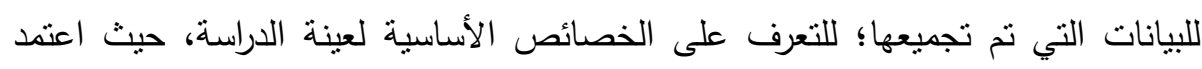
الباحث على المنهج الوصفي التحليلي.

1 - الجداول التكرارية والوسط الحسابى والانحراف المعيارى لاستجابات المبحوثين: يتضمن

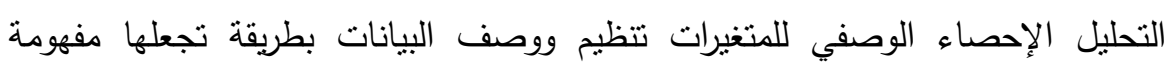
للمستخدم، ولقد قامت الباحثة بوضع إجابات الاسنبانة في جداول تكرارية لكل سؤال وذللك

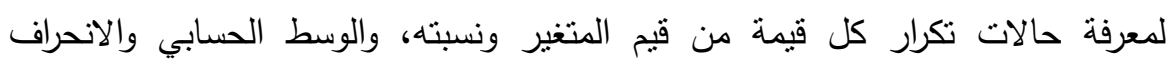
المعياري والثرتيب النسبى لكل متغير الى باقى متغيرات المجموعة.

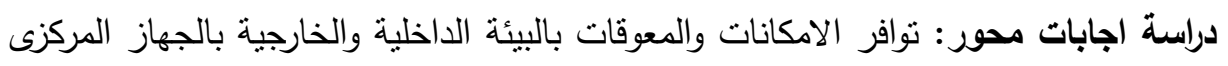
للتنظيم والادارة لتطبيق ادارة الابداع والابتكار من خلال دراسة الاجابات على على العبارات المعنية

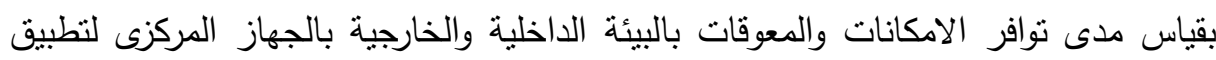

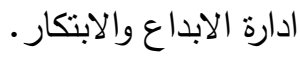


جدول رقم(ه): الاحصاء الوصفى لدحور الامكانات والمعوقات بالبيئة الداخلية والخارجية بالجهاز المركزى للتنظيم والادارة لتطبيق ادارة الابداع والابتكار

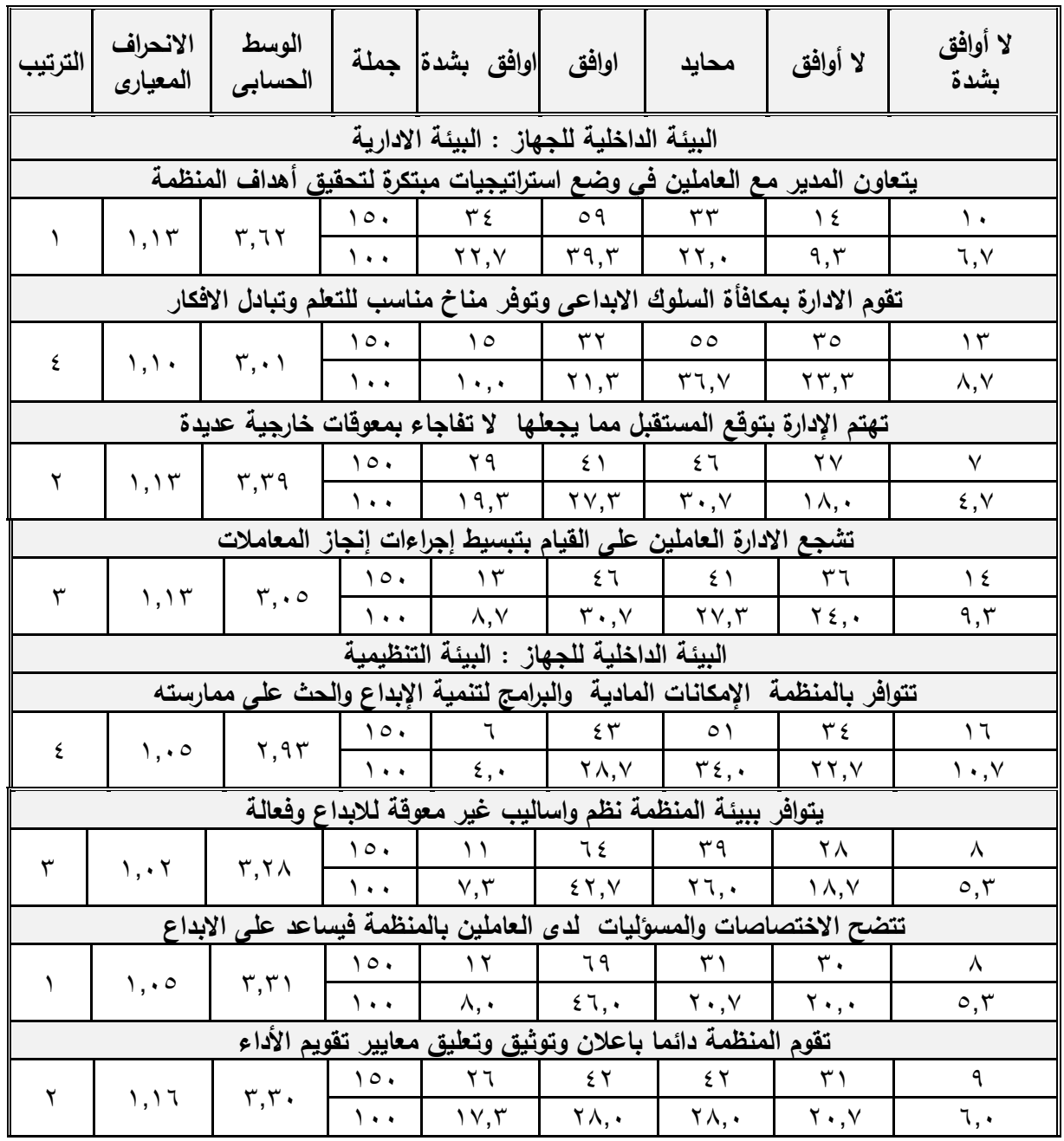


تابع جدول رقم(•) - (ه)

\begin{tabular}{|c|c|c|c|c|c|c|c|c|}
\hline الترتيب & الانحراف & الوسابط & جملة & لمدة & اوافق & \multirow{2}{*}{\multicolumn{2}{|c|}{ محايد }} & لا أوافق \\
\hline \multicolumn{7}{|c|}{ البيئة الخارجية للجهاز : البيئة القانونية والتشريعية } & & \\
\hline \multicolumn{9}{|c|}{ تتلائم أعباء العمل ومجهودك وساعات العمل المقرة بالقوانين مع أجرك } \\
\hline \multirow{2}{*}{ r } & \multirow{2}{*}{$1, \cdot 9$} & \multirow{2}{*}{$r, r_{1}$} & 10. & Ir & 07 & $\leqslant 0$ & ry & 11 \\
\hline & & & $1 \cdots$ & $\wedge, \cdot$ & $r v, r$ & $r \cdot, \cdot$ & $i v, r$ & $\mathrm{~V}, \mathrm{r}$ \\
\hline \multicolumn{9}{|c|}{ تتلائم القوانين والتشريعات المرتبطة باعمال المنظمة ومقدرتها على تثجيع تطبيق الابداع والابتكار. } \\
\hline \multirow{2}{*}{$\varepsilon$} & \multirow{2}{*}{1,11} & \multirow{2}{*}{ r,१ } & 10. & ir & $\leq 0$ & $\leqslant 1$ & \begin{tabular}{l|l}
$\mu$ &
\end{tabular} & r) \\
\hline & & & $1 \ldots$ & $\Lambda$, & $r \cdot, \cdot$ & $r V, r$ & $r \cdot, V$ & $1 \varepsilon$ \\
\hline \multicolumn{9}{|c|}{ تقوم المنظمة بالاهتمام الكافى بمتابعة المتغيرات القانونية والكشف عن الفرص والتهايدات } \\
\hline \multirow{2}{*}{1} & \multirow{2}{*}{$1,1 \mathrm{r}$} & \multirow{2}{*}{ r, rq } & 10. & 17 & 09 & $\S$ & \begin{tabular}{l|l}
$r$ & \\
\end{tabular} & $1 \leq$ \\
\hline & & & $1 \ldots$ & $1 \cdot, \mathrm{V}$ & rq,r & $r V, r$ & Ir, & $9, \Gamma$ \\
\hline \multicolumn{9}{|c|}{ توجد بالبيئة المحيطة بالمنظمة قوانين ولوائح تساعد على تنمية قدراتى الابداعية } \\
\hline \multirow[t]{2}{*}{$r$} & \begin{tabular}{l|l}
1,1 & \\
\end{tabular} & \begin{tabular}{l|l}
1,17 & \\
\end{tabular} & 10. & 11 & 0. & $\Sigma \wedge$ & \begin{tabular}{l|l}
$r \leq$ & \\
\end{tabular} & $\mathrm{V}$ \\
\hline & & & \begin{tabular}{l|l}
$\ldots$ & \\
\end{tabular} & $\mathrm{V}, \mathrm{r}$ & ru, r & rT,. & Tr,V & $\varepsilon, V$ \\
\hline \multicolumn{9}{|c|}{ البيئة الخارجية: البيئة القانونية والثثافية } \\
\hline \multicolumn{9}{|c|}{ تتوافز المعلومات ويسهل الحصول عليها عند الحاجة } \\
\hline \multirow{2}{*}{ r } & \multirow{2}{*}{1,19} & \multirow{2}{*}{ r, үᄉ } & 10. & $r \cdot$ & $0 \wedge$ & $\Gamma \cdot$ & rᄉ & $1 \varepsilon$ \\
\hline & & & 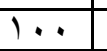 & IT, & $r \wedge, V$ & $r \cdot, \cdot$ & \begin{tabular}{l|l}
$\wedge, V$ &
\end{tabular} & $9, \Gamma$ \\
\hline \multicolumn{9}{|c|}{ تتلائم الاورات التدريبية والمعارف المتاحة للمنظمة مع التخصص الوظيفي للعاملين. } \\
\hline \multirow{2}{*}{1} & \multirow{2}{*}{$1, r \cdot$} & \multirow{2}{*}{ 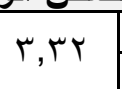 } & 10. & rq & $\leqslant 7$ & $\varepsilon \Gamma$ & $r \cdot$ & 10 \\
\hline & & & $1 \cdots$ & $I V, r$ & $r \cdot, V$ & \multirow{2}{*}{\multicolumn{3}{|c|}{\begin{tabular}{c|c|c|}
$\mu, V$ & $\mid r, r$ & \\
\end{tabular}}} \\
\hline \multirow{3}{*}{\multicolumn{2}{|c|}{ أعمالُه }} & \multirow{3}{*}{ 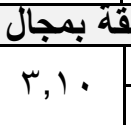 } & هُ المتع| & ث الخارج & المستجا & & & \\
\hline & & & 10. & $1 \varepsilon$ & 0 & $\varepsilon$ & rq & 18 \\
\hline & & & $1 \cdots$ & $q, r$ & r & $r 7, V$ & $19, r$ & $11, r$ \\
\hline & المحيطة & من البيائة & الناتجة م & الازمات & على إدار & لية لكادارز & جد قرة & \\
\hline$\varepsilon$ & & 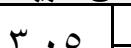 & 10. & $1 \mathrm{~V}$ & ro & 00 & $r \leq$ & 19 \\
\hline$z$ & $1,1 \mathrm{~V}$ & $1, \cdot 0$ & $1 \cdots$ & 11, & $r \mu, r$ & $r q, V$ & $17, \cdot$ & $T r, V$ \\
\hline
\end{tabular}

من خلال الجدول السابق يتبين الاتى:

أولاً: بالنسبة للبيئة الداخلية للجهاز من خلال عنصر البيئة الادارية، نلاحظ أن ترتيب

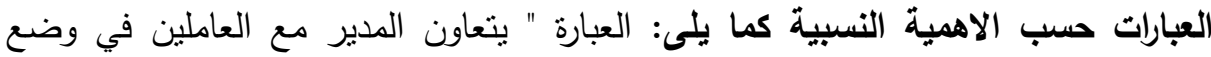
استراتيجيات مبتكرة لتحقيق أهداف المنظمة " جاءت في الترتيب الاول من حيث الاهمية 


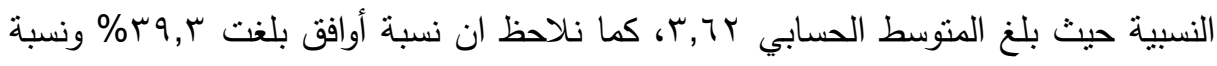

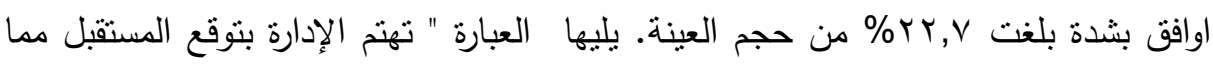

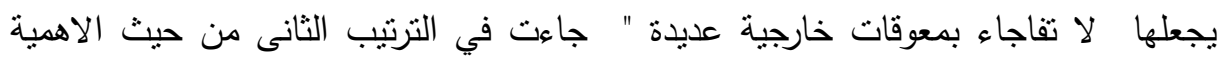

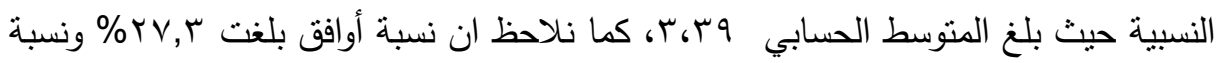

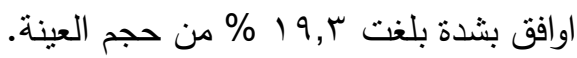
ثانياً: بالنسبة للبيئة الداخلية للجهاز من خلال عنصر البيئة التنظيمية، نلاحظ ان ترتيب العبارات حسب الاهمية النسبية كما يلى: بالئه

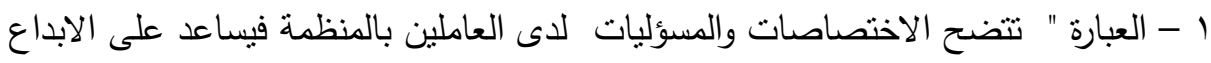

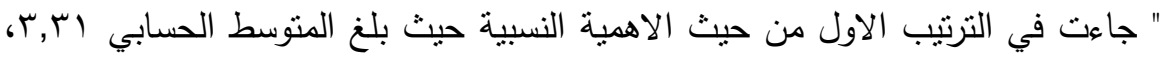

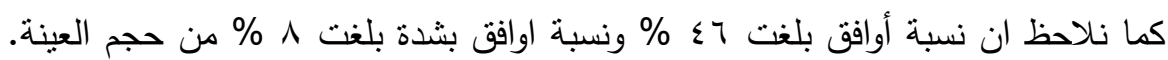

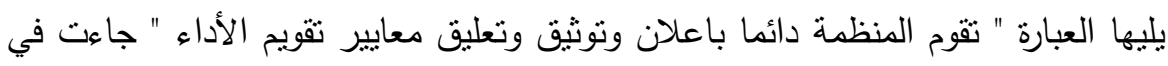

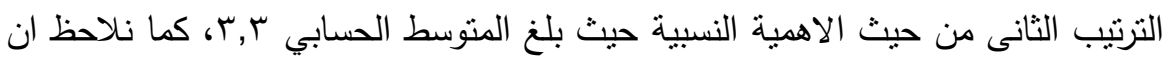

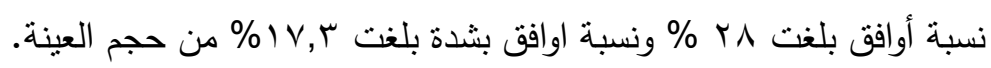

ثالثاً: بالنسبة للبيئة الخارجية للجهاز من خلال عنصر البيئة القانونية والتشريعية ،نلاحظ ان ترتيب العبارات حسب الاهمية النسبية كما يلى: العبارة " تقوم المنظمة بالاهنمام الكافى على علئه بمتابعة المتغيرات القانونية والكثف عن الفرص والتهديدات " جاءت في الترتيب الاول من بن باتهبه حيث الاهية النسبية حيث بلغ المنوسط الحسابي بو,با، كما نلاحظ ان نسبة أوافق بلغت

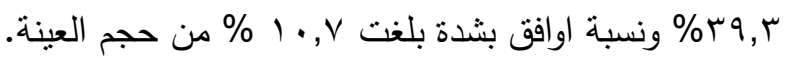

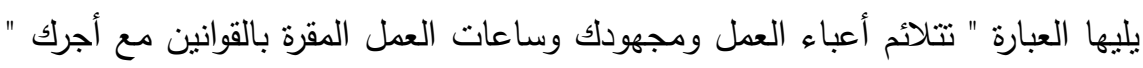

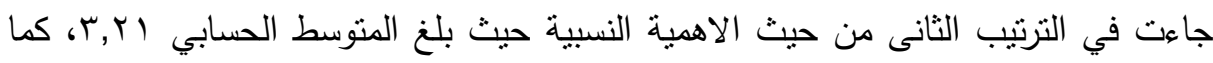

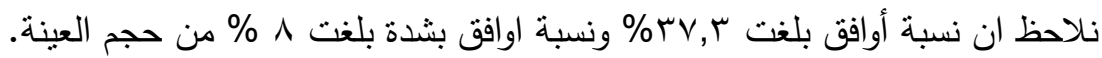


رابعاً: بالنسبة للبيئة الخارجية للجهاز من خلال عنصر البيئة الاجتماعية والثثقافية، نلاحظ ان ترتيب العبارات حسب الاهمية النسبية كما يلى: باليه

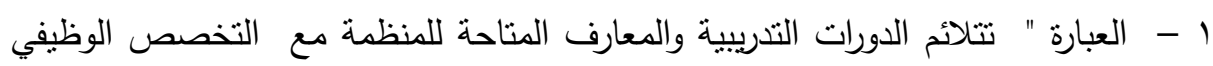
للعاملين بها " جاءت في الترتيب الاول من حيث الاهمية النسبية حيث بلغ المتوسط ولثط

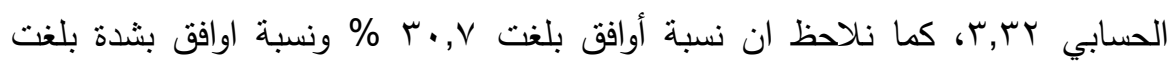

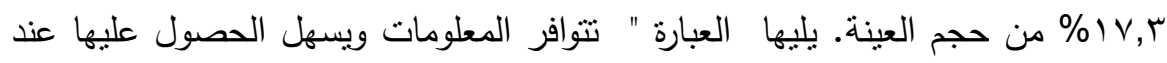
الحاجة " جاءت في الترتيب الثانى من حيث الاهمية النسبية حيث بلغ المتوسط الحسابي لوني

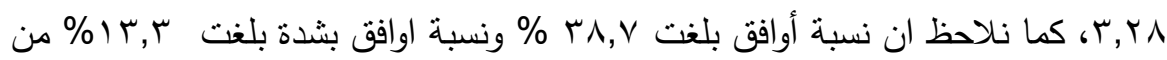
حجم العينة.

T- ثالثاً: اختبارات الفروض الاحصائية: لاختبار فرضيات الدراسة تم استخدام اختبار لعينة واحدة لمعرفة ما اذا كان متوسط درجة الاستجابة قد وصلت الى درجة الموافقة (محايد ) وهى ناخذ القيمة ( ب ) أم لا. لا. الفرضية الصفرية: منتسط درجة الاجابة يساوى ( ب ) وهى تقابل درجة الموافقة ( محايد )

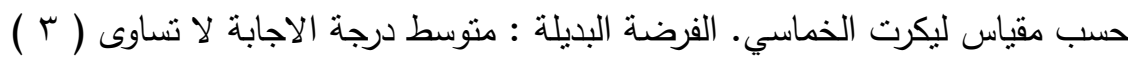

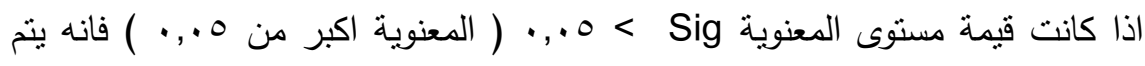

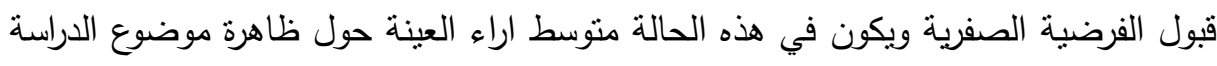

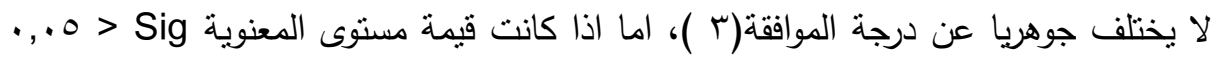
(المعنوية اقل من ه., •) فانه يتم رفض الفرض العدمي وقبول الفرض البديل اى انه يوجد 
اختبار محور " مدى توافر الاككانات والمعوقات البيئية للابداع والابتكار بالجهاز المركزى للتنظيم والادارة " جدول رقم(†): نتائج اختبار محور مدى توافرالاككانات والمعوقات البيئية للابداع والابتكاربالجهاز المركزى للتتظيم والادارة - بالنسبة للبيئة الادارية.

\begin{tabular}{|c|c|c|c|c|c|c|c|c|}
\hline \multirow[b]{2}{*}{ مستوى المعنوية } & \multicolumn{2}{|c|}{ الاجمالى اجى } & \multicolumn{2}{|c|}{ الادارة التتفيذية } & \multicolumn{2}{|c|}{ الادارة الوسطى } & \multicolumn{2}{|c|}{ 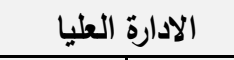 } \\
\hline & $\begin{array}{c}\text { المعنوية } \\
\text { Sig }\end{array}$ & اختبار & $\begin{array}{c}\text { المعنوية } \\
\text { Sig }\end{array}$ & اختبار & $\begin{array}{c}\text { المعنوية } \\
\text { Sig }\end{array}$ & اختبار & $\begin{array}{c}\text { المعنوية. } \\
\text { Sig }\end{array}$ & اختبار \\
\hline \multicolumn{9}{|c|}{ يتعاون المدير مع العاملين في وضع استراتيجيات مبتكرة لتحقيق أهداف المنظمة } \\
\hline معنوى & $\cdot, \cdots$ & $7, \vee \cdot 1$ & $\cdot, \cdots r$ & r,YAV & & $0, .9 r$ & $\cdot, \cdots \wedge$ & r, $9 \vee \cdot$ \\
\hline \multicolumn{9}{|c|}{ تقوم الادارة بمكافأة السلوك الابداعى وتوفر مناخ مناسب للتعلم وتبادل الافكار } \\
\hline غيرمعنوى & $\cdot, 9 \leq 1$ & $\cdot, \cdot \vee \leqslant$ & $\cdot, 1 \times 9$ & $-1,0 \leqslant \leqslant$ & $\cdot, 74 q$ & $\cdot, \leqslant \wedge 0$ & $\cdot, \cdot 1 \mathrm{~V}$ & $r, 7 \cdot 9$ \\
\hline \multicolumn{9}{|c|}{ تهتم الإدارة بتوقع المستقبل مما يجعلها لا تفاجاء بمعوقات خارجية عديدة } \\
\hline معنوى & $\cdot, \cdots$ & $\varepsilon, 191$ & $\cdot, \cdot r \cdot$ & r, rqะ & $\cdot, \cdots 1$ & $r, \varepsilon \backslash V$ & $\cdot, \Gamma \wedge \varepsilon$ & $\cdot, \wedge 9$. \\
\hline \multicolumn{9}{|c|}{ تثجع الادارة العاملين على القيام بتبسيط إجراءات إنجاز المعاملات } \\
\hline غيرمعنوى & $.07 \pi$ &., $0 \vee 9$ & $\cdot, 11 \pi$ & $-1,71 Y$ & $\cdot, Y 10$ & $1,10$. &., .49 & $r, r \circ q$ \\
\hline \multicolumn{9}{|c|}{ على مستوى البيئة الادارية } \\
\hline عيرم & $\cdot, 9 \wedge \wedge$ &., $09 \varepsilon$ & $\cdot, 1 \Gamma \wedge$ & $-1,0 \vee 9$ &., 791 & $\cdot, \Sigma \vee Y$ & $\cdot, \cdot 1 \pi$ & $\varepsilon, 7 Y)$ \\
\hline
\end{tabular}

من نتائج الجدول السابق يتبين ان هناك عبارتين كانتا معنوية سواء على مستوى الطبقات الثناثة وعلى مستوى الاجمالى واخرتين كانتا غير معنوية سواء على مستوى الطبقات

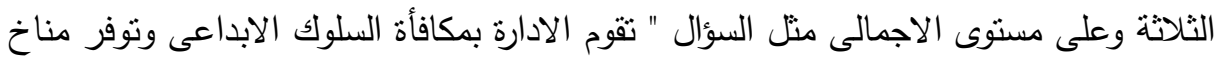

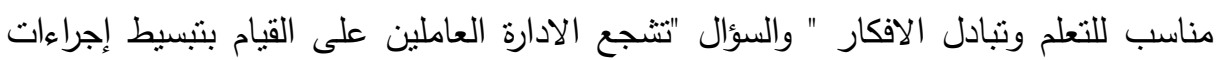

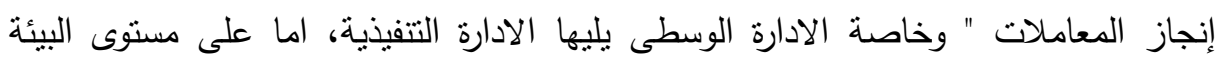

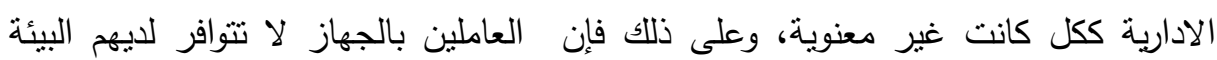

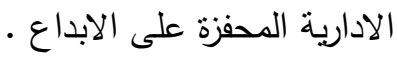


جدول رقم(V): نتائج اختبار محور مدى توافرالامكانات والمعوقات البيئية للابداع والابتكار

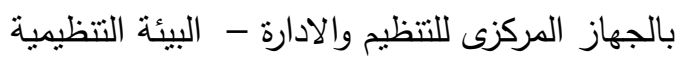

\begin{tabular}{|c|c|c|c|c|c|c|c|c|}
\hline \multirow[b]{2}{*}{ المعنوية } & \multicolumn{2}{|c|}{ 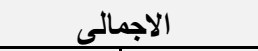 } & \multicolumn{2}{|c|}{ الادارة التنفيذية } & \multicolumn{2}{|c|}{ 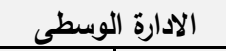 } & \multicolumn{2}{|c|}{ 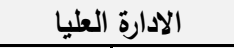 } \\
\hline & المعنوية & اختبار T & المعنوية & 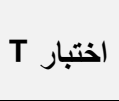 & المعنوية & $\begin{array}{c}\text { اختبار } \\
\text { T }\end{array}$ & المعنوية & 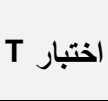 \\
\hline \multicolumn{9}{|c|}{ تتوافر بالمنظمة الإمكانات المادية والبرامج لتنمية الإبداع والحث على ممارسته } \\
\hline 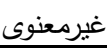 & $\cdot, r q \leq$ & $-\cdot, \wedge 07$ & $\cdot, \ldots r$ & $-r, Y 71$ & $\cdot, 7 \cdot r$ & $\cdot, 0 Y r$ & $\cdot, \cdots \wedge$ & $r, 971$ \\
\hline \multicolumn{9}{|c|}{ يتوافر بييئة المنظمة نظم واساليب غير معوقة للابداع وفعالة } \\
\hline معنوى & $\cdot, \ldots 1$ & $r, r \leq q$ & $1, \ldots$ & $\cdot, \cdots$ & $\cdot, \cdot 1 \cdot$ & r, TY & $\cdot, \ldots$ & $0, \varepsilon \cdot r$ \\
\hline \multicolumn{9}{|c|}{ تتضح الاختصاصات والمسؤليات لاى العاملين بالمنظمة فيساعد على الابداع } \\
\hline معنوى & $\cdot, \cdots$ & $r, 700$ & $\cdot, \cdot \leq 7$ & $r, \cdot T \leq$ & $\cdot, \cdot \wedge \leq$ & $1, v \leq 9$ & $\cdot, \cdots 1$ & $r, \wedge \vee r$ \\
\hline \multicolumn{9}{|c|}{ تقوم المنظمة دائما باعلان وتوثيق وتعليق معايير تقويم الأداء } \\
\hline 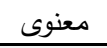 & $\cdot, \cdots$ & $r, 1 \vee 0$ & $1, \cdot \leq r$ & $\cdot, \ldots$ & $\cdot, \cdot r q$ & r, r rq & $\cdot, \cdots$ & $0, \Sigma \vee V$ \\
\hline \multicolumn{9}{|c|}{ على مستوى البيئة التظيمية } \\
\hline معنوى & $\cdot, \cdots r$ & $r, r \leq q$ & $1,7$. & $\cdot, \cdots$ & $\cdot, \cdot 11$ & r, ז & $\cdot, \cdots$ & $0, \vee \vee r$ \\
\hline
\end{tabular}

من نتائج الجدول السابق يتنين ان جميع العبارات كانت معنوية سواء على مستوى الطبقات الثلاثة وعلى مستوى الاجمالى اما السؤال " تتوافر بالمنظمة الإمكانات المادية والبرامج لتتمية الإبداع والحث على ممارسته في المنظمة " فكان غير معنوى وخصوصا الادارة الوسطى يليها الادارة التتفيذية، اما على مستوى البيئة التتظيمية ككل كانت معنوية،

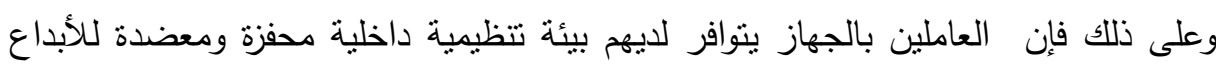

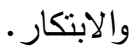


جدول رقم(^): نتائج اختبار محور مدى نوافرالاككانات والمعوقات البيئية الخارجية للابداع

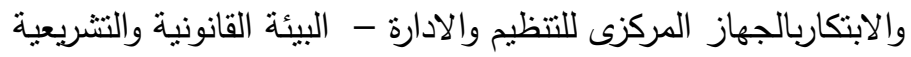

\begin{tabular}{|c|c|c|c|c|c|c|c|c|}
\hline \multirow{2}{*}{ المعنوية } & \multicolumn{2}{|c|}{ الاجمالى } & \multicolumn{2}{|c|}{ الادارة التنفيذية } & \multicolumn{2}{|c|}{ الادارة الوسطى } & \multicolumn{2}{|c|}{ 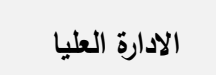 } \\
\hline & المعنوية & 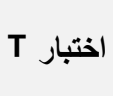 & المعنوية & 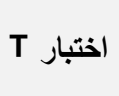 & المعنوية & $\begin{array}{c}\text { اختبار } \\
\text { T }\end{array}$ & المعنوية & $\begin{array}{c}\text { اختبار } \\
\text { T }\end{array}$ \\
\hline \multicolumn{9}{|c|}{ تتلائم أعباء العمل ومجهودك وساعات العمل المقرة بالقوانين مع أجرك } \\
\hline 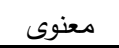 & $\cdot, \cdot 10$ & $r, \Sigma T V$ & $\cdot, \vee \cdot 9$ & $\cdot$ r rVo & $\cdot, \cdot \leqslant \wedge$ & $r, \ldots q$ & $\cdot, \cdot 1 \leq$ & $r, T \wedge r$ \\
\hline \multicolumn{9}{|c|}{ تتلائم القوانين والتشريعات المرتبطة باعمال المنظمة ومقدرتها على تشجيع تطبيق الابداع والابتكار } \\
\hline 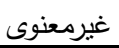 & $\cdot, \mathrm{V} \wedge \mathrm{r}$ & $-\cdot, Y \vee \top$ & $\cdot, 1 \vee \cdot$ & $-1, r q$. & $\cdot, \wedge \Sigma 1$ & $\cdot, Y \cdot 1$ & $\cdot, 1 \mu$ & $1,0 \wedge 1$ \\
\hline \multicolumn{9}{|c|}{ تقوم المنظمة بالاهتمام الكافى بمتابعة المتغيرات القانونية وإلكشف عن الفرص والتهديدات } \\
\hline 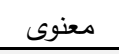 & $\cdot, \cdots r$ & $r, I r v$ & $\cdot, 1 \leq V$ & $1, \leqslant \vee 1$ & $\cdot, .07$ & $1,9 \leq \leq$ & $\cdot, \cdot r \cdot$ & 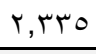 \\
\hline \multicolumn{9}{|c|}{ توجد بالبيئة المحيطة بالمنظمة قوانين ولوائح تساعد على تنمية قراتى الابداعية } \\
\hline غيرمعنوى & $\cdot, .0 \leq$ & 1,949 & 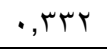 & $-\cdot, 9 \wedge$. & $\cdot, \cdot r \leq$ & $r, 1 Y T$ & $\cdot, \cdot 1 \cdot$ & $r, \wedge r \wedge$ \\
\hline \multicolumn{9}{|c|}{ على مستوى البيئة القانونية والتشريعية } \\
\hline معنوى & $\cdot, \cdot 11$ & r, I Yo & $\cdot, \cdot 1 \leq$ & $1, \mathrm{~V} \backslash \leq$ & $\cdot, \cdot 70$ & ב & $\cdot, \cdot r \cdot$ & $r, 9 \leq 0$ \\
\hline
\end{tabular}

من نتائج الجدول السابق يتبين ان هنالك عبارتين كانتا معنوية سواء على مستوى

الطبقات التلاثة وعلى مستوى الاجمالى واخرتين كانتا غير معنوية سواء على مستوى الطبقات

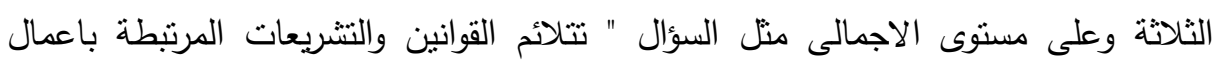

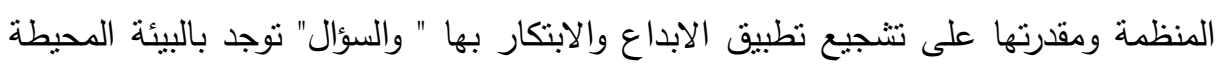
بالمنظمة قوانين ولوائح تساعد على تتمية قدراتى الابداعية ". وخصوصا الادارة الوسطى يليها

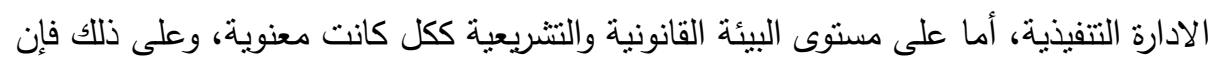
العاملين بالجهاز تتوافر لديهم البيئة القانونية والتشريعية المحفزة على الابداع. 
جدول رقم(9): نتائج اختبار محور مدى توافرالامكانات والمعوقات البيئية الخارجية للابداع

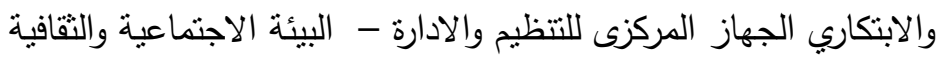

\begin{tabular}{|c|c|c|c|c|c|c|c|c|}
\hline \multirow[b]{2}{*}{ المعنوية } & \multicolumn{2}{|c|}{ الاجمالى } & \multicolumn{2}{|c|}{ الادارة التنفيذية } & \multicolumn{2}{|c|}{ الادارة الوسطى } & \multicolumn{2}{|c|}{ الادارة العليا } \\
\hline & $\begin{array}{c}\text { المعنوية. } \\
\text { Sig }\end{array}$ & $\begin{array}{c}\text { اختبار } \\
\text { T }\end{array}$ & المعنوية & 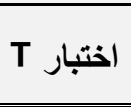 & $\begin{array}{c}\text { المعنوية. } \\
\text { Sig }\end{array}$ & 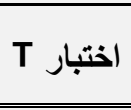 & $\begin{array}{c}\text { المعنوية. } \\
\text { Sig }\end{array}$ & $\begin{array}{c}\text { اختبار } \\
\text { T }\end{array}$ \\
\hline \multicolumn{9}{|c|}{ تتوافز المعلومات ويسهل الحصول عليها عند الحاجة } \\
\hline معنوى & $\cdot, \cdots \leq$ & $r, \wedge \wedge \vee$ & $\cdot, 9 \cdot 7$ & $-\cdot, 119$ & $\cdot, \cdot Y_{1}$ & r,rqV & $\cdot, \cdots$ & $\varepsilon, 9 \leq q$ \\
\hline \multicolumn{9}{|c|}{ تتلائم الدورات التدريبية والمعارف المتاحة للمنظمة مع التخص الوظيفي للعاملين بها. } \\
\hline معنوى & $\cdot, \cdots 1$ & r,YTo &., 109 & $1, \varepsilon Y \wedge$ & $\cdot, \wedge \varepsilon$ & $1, \times 01$ & $\cdot, \cdot r$ & $r, \varepsilon \leqslant r$ \\
\hline \multicolumn{9}{|c|}{ يتم تعريف الموظقين بكل المستجدات الخارجية المتعلقة بمجال أعمالهم } \\
\hline غعنوى & $\cdot, Y q \leq$ & $1, .04$ & $\cdot, \vee \vee 99$ & $\cdot, Y \circ T$ & . 9Y7 & $\cdot, .94$ & $\cdot, \cdot r \leq$ & $r, \varepsilon T \leqslant$ \\
\hline \multicolumn{9}{|c|}{ توجد قرة عالية للادارة على إدارة الأزمات الناتجة من البيئة المحيطة } \\
\hline غعنوى & - TYO & $\cdot, \leqslant 9$. & $\cdot, \wedge \cdot \wedge$ & $-\cdot, r \leq \varepsilon$ & $\cdot, \vee \vee \vee \varepsilon$ & $-\cdot, Y \wedge \wedge$ & $\cdot, \cdot r \varepsilon$ & $r, \varepsilon T \leqslant$ \\
\hline \multicolumn{9}{|c|}{ على مستوى البيئة الاجتماعية والثقافية } \\
\hline معنوى & $\cdot, \cdot r$ & r, &., 119 & $1, \pi) \wedge$ & $\cdot, \cdot 11$ & 1,941 & $\cdot, \ldots r$ & $\varepsilon, \Gamma, Y$ \\
\hline
\end{tabular}

من نتائج الجدول السابق ينتين ان هناك عبارتين كانتا معنوية سواء على مستوى الطبقات الثلاثة وعلى مستوى الاجمالى واخرنين كانتا غير معنوية سواء على مستوى الطبقات الثلاثة وعلى مستوى الاجمالى منل السؤال " يتم تعريف الموظفين بكل المستجدات الخارجية المتعلقة بمجال أعمالهم " و" توجد قدرة عالية للادارة على إدارة الأزمات الناتجة من البيئة

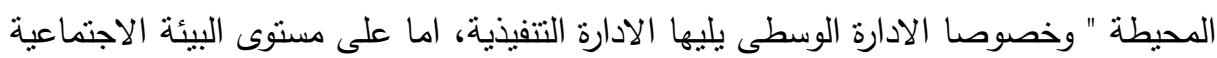
والثقافية ككل كانت معنوية، وعلى ذلك فإن بيئة الجهاز تتوافر بها امكانات البيئة الاجتماعية والثقافية المحفزة على الابداع. 


\section{تئائج السراسة}

من خلال الاراسة الاحصائية الى تمت على عينة البحث توصل الباحث الى النتائج التالية: 1- بالنسبة للبيئة الادارية وجد أن الادارة تشجع العاملين على القيام بتبسيط إجراءات إنجان النجاز

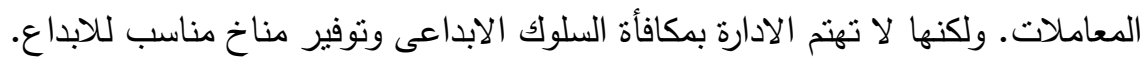

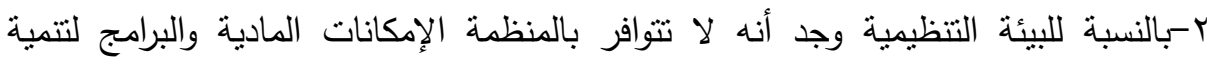
الإبداع والحث على ممارسته.

r- بالنسبة للبيئة النقافية والاجتماعية وجد انه لا يتم تعريف الموظفين بكل المستجدات

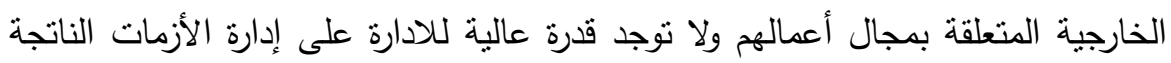
من البيئة المحيطة

ع - بالنسبة لبيئة القوانين والنتريعات وجد أن القوانين والتشريعات المرتبطة باعمال المنظمة لا تتلائم ومقدرتها على نتجيع تطبيق الابداع والابتكار بها. وتوجد بالبيئة المحيطة ولتهنة بالمنظمة قوانين ولوائح تحد من تتمية القدرات الابداعية.

\section{اللتوكيايت}

بناء على النتائج التي توصلت إليها الدراسة يوصي الباحث بوعى الادارة العليا بالجهاز

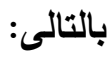
• تنبى أساليب لتتمية الاتجاهات الابتكارية والإبداعية وينبغى أن يشجع عليها بشكل واضح ومخطط خاصة فى عمليات التوظيف، وانتقاء الأجهزة الإدارية. • تطويرالمهارات التتظيمية والقيادية فى الإدارات العليا لاتباع التفكيرالإبداعى.

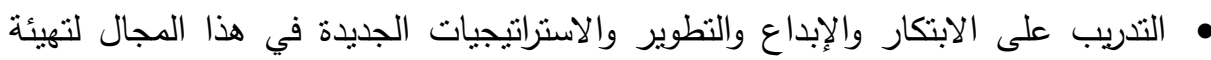
المناخ المناسب للإبداع والابتكارات. إتباع نظام التعليم والتدريب الابتكاري التي يتجاوز الطرق الثقليدية، ويبحث عن الطرق الفعالة للتعليم والتدريب التي تكسب الفرد المزيد من المعارف والمهارات المنطورة. 
• تحفيز القدرات الإبداعية الفردية والجماعية المتوفرة، وخلق المناخ المناسب لها، وإيجاد

الظروف الملائمة لها للبحث وتخصيص الميزانيات المناسبة مع تفجير الطاقات الكامنة. ه دراسة المتغيرات الداخلية والخارجية التي تمنع المؤسسات من الوصول إلى مستوى الريادة

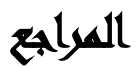

منذر العكور: أثر الثقافة التنظيمية فى تحقيق الابداع الادارى لدى العاملين فى وزارة

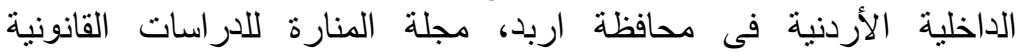

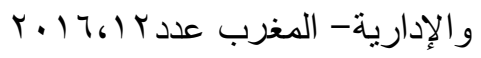

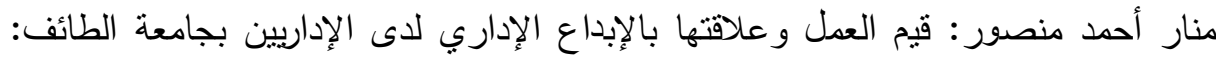

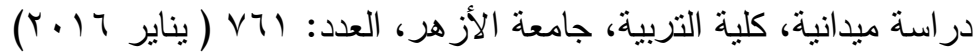

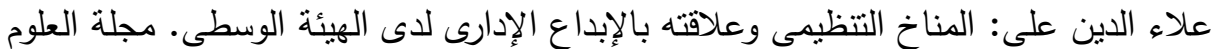

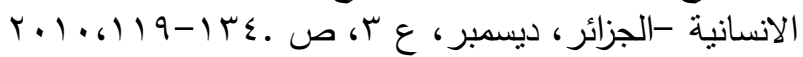

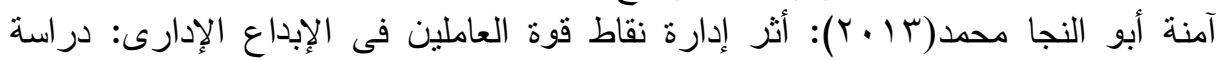

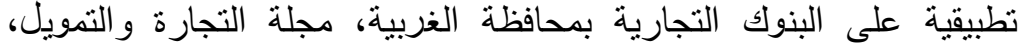

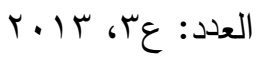

محمد التويجري، هيلة بنت منديل: الإبداع الإداري وعلاقته بالاداء الوظيفي للعاملين الإداريين

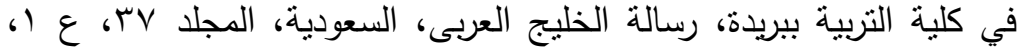

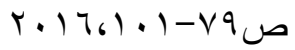

أميمة حلمي مصطفي واخرون:" درجة توافر عناصر الإبداع الإداري لإى مديري المدارس

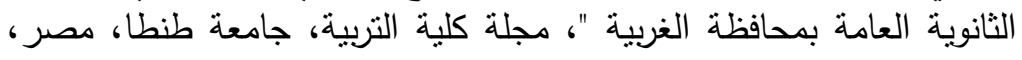

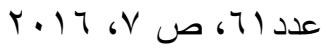

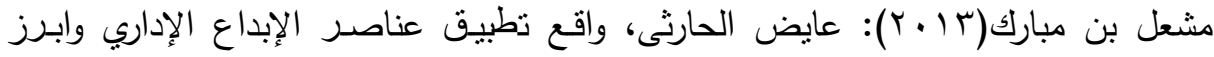

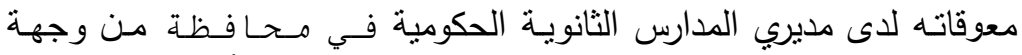
نظر ومديريها ووكلائها، رسالة ماجستير منشورة: جامعة أم القرى - كلية فية ونية

$$
\text { التربية }
$$


Fredricka K. Reisman, Creativity in Business, Research Papers on Knowledge, Innovation and Enterprise Volume II, International Conference on Knowledge, Innovation \& Enterprise,11-15August2015,Istanbul, Turkey.

Arthur D Little, 2013: Getting a Better Return on Your Innovation Investment, , Technology and Innovation Management.

Lina Girdauskiene \& others ,2012:Human Resource Management in a Creative Organization, International Confrence On Economics Markting and Management IPDR Vol.28

Marjolein C.J. Caniëls, Organizing Creativity, 2013: Creativity and Innovation under Constraints, Blackwell Publishing Ltd, Volume 22 Number 1.

David H. Cropley, James C. Kaufman, Arthur J. cropley" Measuring Creativity for Innovation Management", Journal of Technology Management \& Innovation,. 2011, Volume 6, Issue 3, p 15. 


\title{
ENVIRONMENTAL IMPACT OF USING INNOVATION AND CREATION MANAGEMENT APPLIED STUDY ON THE CENTRAL AGENCY FOR ORGANIZATION AND ADMINISTRATION
}

Sobh, M. M. ${ }^{(1)}$; Ahmed, Kh. H. ${ }^{(2)}$ and Hemdan, Somaya, H. ${ }^{(3)}$

1) Busines Dept. Faculty of Commerce, Ain Shams University

2) Accounting Dept. Faculty of Commerce, Ain Shams University

3) Central Agency for Organization and Administration

\begin{abstract}
The organizations aim at efficiency, prosperity and growth, which requires to learn new methods of management, in order to face the contemporary challenges, while working to achieve their goals. Whereas the environmental impact of the use of innovation and creation management in government units is focused on addressing the internal and external environmental changes of these units, which relates to the developments that have resulted from the information revolution and the technological trend in the business, which necessitates the organizations to respond to these developments by making the modifications that accompany these developments. Responding to new ideas and modern methods that enable organizations to address these challenges and problems. Where different organizations face many issues and problems that require their leaders and employees to think about reducing the reliance on the traditional approach based on trying and error in solving problems, and try to employ the creative approach in this regard. The management writers and managers today think that the need for organizations to Administrative innovation is an urgent need imposed by economic, social, political, cultural and other changes in society, as well as the changing and complex circumstances of
\end{abstract}

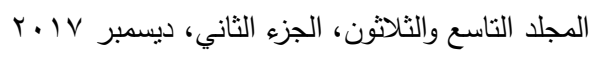


contemporary organizations. The internal environment of governmental organizations in terms of administrative leadership and organizational aspects, as well as the external environment of governmental organizations in terms of legislation and governing laws and the surrounding cultural and social aspects affecting them may be hindered or counteracting the creativity and administrative innovation of these organizations, thus affecting the services provided To citizens and to the environment surrounding the organization positively or negatively by degree of empowerment or restriction of creativity and innovation in those organizations (Muhammad et al.,2016). Therefore, the research deals with the environmental impact of using the management of creativity and innovation in governmental organizations by applying them to the central organization for management and administration, in order to improve the performance of the system and the employees.

Keywords: administrative innovation, management of creativity, internal environment of the organization, external environment of the organization 